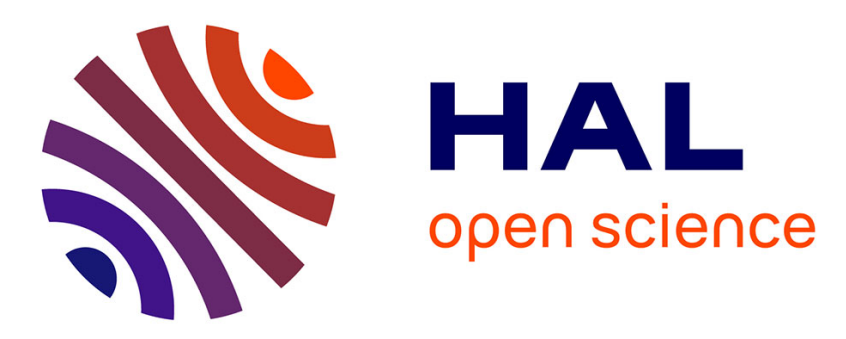

\title{
Zinc speciation and isotopic exchangeability in soils polluted with heavy metals
}

William E. Diesing, Sokrat Sinaj, Geraldine Sarret, Alain Manceau, T. Flura, Paolo Demaria, A. Siegenthaler, Valérie Sappin-Didier, Emmanuel Frossard

\section{- To cite this version:}

William E. Diesing, Sokrat Sinaj, Geraldine Sarret, Alain Manceau, T. Flura, et al.. Zinc speciation and isotopic exchangeability in soils polluted with heavy metals. European Journal of Soil Science, 2008, 59 (4), pp.716-729. 10.1111/j.1365-2389.2008.01032.x . hal-00311803

\section{HAL Id: hal-00311803 \\ https://hal.science/hal-00311803}

Submitted on 21 Aug 2008

HAL is a multi-disciplinary open access archive for the deposit and dissemination of scientific research documents, whether they are published or not. The documents may come from teaching and research institutions in France or abroad, or from public or private research centers.
L'archive ouverte pluridisciplinaire HAL, est destinée au dépôt et à la diffusion de documents scientifiques de niveau recherche, publiés ou non, émanant des établissements d'enseignement et de recherche français ou étrangers, des laboratoires publics ou privés. 
$1 \quad$ Zn exchangeability in soils

2

European Journal of Soil Science, August 2008, 59, 716-729

doi: 10.1111/j.1365-2389.2008.01032.x

3 Zinc speciation and isotopic exchangeability in soils polluted with

4 heavy metals

5

6

7 W.E. Diesing ${ }^{\text {a }}$, S. SinAJ ${ }^{\mathrm{a}}$, G. SARRET ${ }^{\mathrm{b}}$, A. MANCEAU $^{\mathrm{b}}$, T. FlurA $^{\mathrm{a}}$, P. DEMARIA $^{\mathrm{a}}$, A.

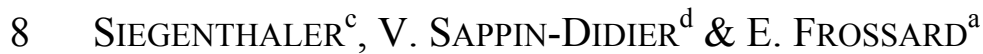

$9{ }^{a}$ Swiss Federal Institute of Technology (ETH Zürich), Institute of Plant Sciences,

10 Eschikon 33, CH-8315 Lindau, Switzerland; ${ }^{b}$ Environmental Geochemistry Group,

11 LGIT, University of Grenoble and CNRS, BP 53, 38041, Grenoble Cedex 9, France;

$12{ }^{c}$ Swiss Federal Office for Agriculture (BLW), Mattenhofstrasse 5, 3003 Bern,

13 Switzerland; and ${ }^{d}$ Institut National de la Recherche Agronomique (INRA), UMR

14 Transfert sol plante et cycle des éléments minéraux dans les écosystèmes cultivés,

15 BP 81, 33883 Villenave d'Ornon Cedex, France

16

17 Correspondence: E. Frossard, E-mail: emmanuel.frossard@ipw.agrl.ethz.ch 


\section{Summary}

26 A correct characterization of heavy metal availability is a prerequisite for the

27 management of polluted soils. Our objective was to describe zinc ( $\mathrm{Zn})$ availability in

28 polluted soils by measuring the isotopic exchangeability of $\mathrm{Zn}$ in soil/solution ( $E$

29 value) and in soil/plant systems ( $L$ value), by assessing the transfer of $\mathrm{Zn}$ and ${ }^{65} \mathrm{Zn}$ in

30 the fractions of a six-step selective sequential extraction (SSE) in incubated soils

31 and by identifying $\mathrm{Zn}$ forms in soils using extended X-ray absorption fine structure

32 (EXAFS) spectroscopy. We distinguished 3 pools of exchangeable $\mathrm{Zn}$ : the pool of

33 Zn exchangeable within 1 minute which is observed in all soils, Zn exchangeable on

34 the medium term, and the slowly and not exchangeable $\mathrm{Zn}$. The amount of $\mathrm{Zn}$

35 present in the 2 first pools was similar to the $L$ value measured with $T$. caerulescens.

36 The 3 first steps of the SSE solubilized the $1^{\text {st }}$ pool and a fraction of the $2^{\text {nd }}$ pool.

37 Most of the $2^{\text {nd }}$ pool and a fraction of the $3^{\text {rd }}$ pool were extracted in the $4^{\text {th }}$ step of

38 the SSE, while the rest of the $3^{\text {rd }}$ pool was extracted in the final steps of the SSE.

39 The EXAFS study conducted on two soils showed that more than half of the Zn was

40 present in species weakly bound to organic compounds and/or outer sphere

41 inorganic and organic complexes. Other species included strongly sorbed Zn species

42 and Zn species in crystalline minerals. The EXAFS study of selected SSE residues

43 showed that the specificity and the efficiency of the extractions depended on the

44 properties of the soil studied.

\section{Introduction}

47 An accurate assessment of heavy metal availability is essential for the proper

48 management of polluted soils. Young et al. (2006) reviewed the use of selective

49 sequential extractions (SSE) and isotope exchange (IE) techniques to characterize 
50 heavy metals availability and speciation on the solid phase of soils. They concluded

51 that although sequential extractions are rather easy to implement, their results are

52 flawed because of the lack of specificity of the extractants for given metal species,

53 and/or because of the adsorption or precipitation of metals occurring during the

54 extraction. IE techniques conducted in soil/solution systems allow the quantification

55 of ions located on the solid phase of the soil that can exchange with the same ion

56 present in the soil solution within a given exchange time ( $E$ value) (Sinaj et al.,

57 1999). Ayoub et al. (2003) and Sinaj et al. (2004) showed that $E$ values measured

58 after a long IE time in acidic soils are identical to the amount of isotopically

59 exchangeable $\mathrm{Zn}$ measured in pot experiments with different plant species $(L$

60 values) demonstrating that $\mathrm{Zn}$ that is isotopically exchangeable within a time frame

61 relevant for plant growth is the main source of $\mathrm{Zn}$ for plant nutrition. In most studies

$62 E$ values are only measured after a single time of exchange (for instance 24h; Young

63 et al., 2000; Degryse et al., 2003; Nolan et al., 2005) although according to Young

64 et al. (2006) the study of the kinetics of IE has a lot of potential for assessing Zn

65 forms and availability in soils.

66 To assess whether a SSE could deliver relevant results on cadmium $(\mathrm{Cd})$

67 availability, Ahnstrom and Parker (2001) carried out a sequential extraction on soils

68 that had been labeled with a stable isotope of $\mathrm{Cd}\left({ }^{111} \mathrm{Cd}\right)$. They measured in all

69 extracts the total $\mathrm{Cd}$ content and the abundance of ${ }^{111} \mathrm{Cd}$ and then compared these

70 results with the amount of soil isotopically exchangeable $\mathrm{Cd}$. They concluded that

71 no single fraction of the sequential extraction or a combination of fractions

72 corresponded to the size of the isotopically labile $\mathrm{Cd}$ pool.

73 Extended X-ray Absorption Fine Structure (EXAFS) spectroscopy is also

74 used to assess the forms of heavy metals in soils (Manceau et al., 2002). Sarret et al. 
75 (2004) explained the high proportion of isotopically exchangeable $\mathrm{Zn}$ observed in a 76 polluted soil by its high concentration in octahedral $\mathrm{Zn}$ weakly bound to organic 77 compounds identified with EXAFS. The sensitivity of EXAFS spectroscopy for 78 exchangeable species (bound to organics or weakly sorbed on minerals) is however 79 relatively weak as compared to precipitated and crystalline phases. On the opposite, 80 chemical extractions allow a better quantification of easily mobilized species as 81 compared to more recalcitrant ones due to non-specific dissolution and possible 82 formation of new species. Therefore, the combination of IE methods, SSE and 83 EXAFS spectroscopy may provide a better picture of exchangeable and non84 exchangeable metal species (Scheinost et al., 2002; Sarret et al., 2004).

85 We analyzed Zn exchangeability and speciation in six polluted soils with IE 86 methods, both in soil/water systems ( $E$ values) and in soil/plant systems ( $L$ values),

87 SSE and Zn K-edge EXAFS spectroscopy. Our purpose was to establish 88 relationships between the $\mathrm{Zn}$ pools determined by the various techniques, and 89 between these pools and soil parameters such as total $\mathrm{Zn}$ content and $\mathrm{pH}$. Moreover, 90 the specificity of SSE steps for extracting real Zn chemical species was tested by 91 comparing the distribution of Zn species determined by EXAFS spectroscopy in the 92 soil and in selected extraction residues. To test whether the extraction steps released $93 \mathrm{Zn}$ species with a specific exchangeability, soils were labeled with ${ }^{65} \mathrm{Zn}$ before the 94 SSE, and the specific activity was measured in each residue.

95

96 Materials and methods

97 Soils

98 We studied six soils that had been polluted with heavy metals. The soil from the 99 Institut National de la Recherche Agronomique (INRA soil) was sampled from a 
100 field experiment performed near Bordeaux, France ( $\left.44^{\circ} 51^{\prime} \mathrm{N} 00^{\circ} 32^{\prime} \mathrm{W}\right)$. This soil

101 had received $100 \mathrm{t}$ of municipal digested and dehydrated sewage sludge per hectare

102 every second year between 1974 and 1993. A description of the experiment can be

103 found in Weissenhorn et al. (1995). Two soils from the Institut für Umweltschutz

104 und Landwirtschaft (IUL soils) were collected in a field experiment conducted near

105 Bern, Switzerland $\left(46^{\circ} 55^{\prime}{\mathrm{N} 07^{\circ}}^{2} 5^{\prime} \mathrm{E}\right)$. Aerobically digested and dehydrated

106 sewage sludge had been applied to the IUL SS soil, while pig slurry had been

107 applied to the IUL PS soil. The amendment-loading rate for both soils was $5 \mathrm{tha}^{-1}$

108 year $^{-1}$ from 1976 to 1996. A description of this field experiment is given in

109 Siegenthaler et al. (1999). The three remaining soils were collected in the vicinity of

110 industrial metal smelting facilities located close to Dornach, Switzerland $\left(47^{\circ} 25^{\prime} \mathrm{N}\right.$

$\left.11107^{\circ} 35^{\prime} \mathrm{E}\right)$, and in Evin $\left(50^{\circ} 25^{\prime} \mathrm{N} 03^{\circ} 01^{\prime} \mathrm{E}\right)$ and Mortagne $\left(50^{\circ} 30^{\prime} \mathrm{N} 03^{\circ} 27^{\prime} \mathrm{E}\right)$,

112 France. The Dornach soil has accumulated $\mathrm{Cd}, \mathrm{Cu}, \mathrm{Ni}$ and $\mathrm{Zn}$ from the deposition of

113 about $700 \mathrm{t}$ dust year ${ }^{-1}$ from brass smelting that began in 1895 and continued into

114 the 1980s before the installation of emission filters and scrubbers (Geiger et al.,

115 1993). The smelting facility in Evin began operations in 1894 and grew to become

116 the largest $\mathrm{Pb}$ and $\mathrm{Zn}$ ore processing plant in Europe before its closure in 2003. Until

117 1970, the Evin facility emitted approximately $5 \mathrm{t}$ smelter dust day ${ }^{-1}$ (LASIR, 2000).

118 The Mortagne soil is heavily polluted with metal dust and slag from a $\mathrm{Pb}$ and $\mathrm{Zn}$

119 smelter in operation between 1906 and 1968 (Manceau et al., 2000). Thiry et al.

120 (2002) estimate that $15^{\prime} 000 \mathrm{t}$ of metals have been dispersed over 25 hectares

121 surrounding the smelter.

122 Approximately 100 subsamples of the INRA, IUL SS and IUL PS soils were

123 collected at random intervals within the surface horizon $(0-20 \mathrm{~cm})$ to obtain a

124 representative sample. For the Evin and Dornach soils, samples were randomly 
125 taken after having removed the litter layer to obtain the maximum contaminant

126 concentration in the soil. The sample site in Mortagne is the so-called metallicolous

127 meadow. The A horizon was characterized by a distinct layer (5 to $8 \mathrm{~cm}$ thick)

128 starting at a 15 to $25 \mathrm{~cm}$ depth in which smelter ash and tailings had been spread out

129 and buried at the time the smelter was closed. A representative sampling was

130 obtained by collecting approximately 100 random subsamples between 5 and $40 \mathrm{~cm}$

131 to include the heavily polluted layer. The soil samples were well mixed, air-dried for

132 at least one week and passed through a 2-mm sieve. Remaining plant debris was

133 removed by hand prior to analysis. Relevant soil characteristics are listed in Table 1.

135 Isotopic exchange kinetics, compartmental analysis and determination of 136 isotopically exchangeable Zn

137 IE kinetic experiments were carried out using a 1:10 soil solution ratio and $2 \mathrm{mM}$

$138 \mathrm{CaCl}_{2}$ as described by Sinaj et al. (1999). After shaking the soil solution suspension

139 on an end-over-end shaker for three days, the samples were removed, placed on a

140 magnetic stirring plate and stirred at $300 \mathrm{rpm}$. The soil suspension samples were

141 spiked with 1.3 to $2.5 \mathrm{kBq}$ of carrier-free ${ }^{65} \mathrm{Zn}$ added as $\mathrm{ZnCl}_{2}$ (NEN Biosciences,

142 Boston, USA; specific activity $2.0 \mathrm{GBq} \mathrm{mg}^{-1} \mathrm{Zn}$ ). Aliquots of the soil suspension

143 filtered through a $0.2 \mu \mathrm{m}$ porosity cellulose acetate membrane (Minisart, Sartorius)

144 were removed at 1, 3, 10, 30 and 60 minutes, and at 1, 7 and 14 days. After the first

14560 minutes of IE the flasks were left on the bench and they were put back on the

146 stirring plate one hour before sampling at 1,7 and 14 days so as to minimize the

147 dispersion of soil aggregates that would have been caused by a continuous stirring.

148 The concentration of $\mathrm{Zn}$ in the solution $\left(C_{\mathrm{Zn}}\right)$ was measured after 60 minutes, 1,7

149 and 14 days by ion chromatography as proposed by Sinaj et al. (1999). This method 
150 measures the oxalate complexable $\mathrm{Zn}$ in the filtered soil suspension which 151 approximates the concentration of the hydrated and weakly complexed $\mathrm{Zn}$ species 152 (Cardellicchio et al., 1999) present in the solution. ${ }^{65} \mathrm{Zn}$ activity in the solution was 153 measured at all sampling times by $\beta$ liquid scintillation detection (Packard 2500) at 154 an emission energy of $325 \mathrm{keV}$. We measured the $\beta$-counts using $1 \mathrm{ml}$ of filtrate 155 with $5 \mathrm{ml}$ of scintillation liquid (Packard Ultima Gold) and corrected them for 156 quenching effects.

157 The decrease of the fraction of radioactivity remaining in the solution $\left(r_{t} / R\right.$ 158 where $r_{t}$ is the radioactivity remaining in the solution expressed in $\mathrm{Bq}$ after $t$ 159 minutes, and $R$ the total introduced radioactivity expressed in $\mathrm{Bq}$ ) was analyzed in 160 each soil with a compartmental analysis to assess the number of $\mathrm{Zn}$ containing 161 compartments (a compartment is defined as an amount of material that acts as 162 though it is well-mixed and kinetically homogeneous, Cobelli et al. (2000)). We 163 proceeded as proposed by Cobelli et al. (2000). If we consider that for a given soil 164 an apparent isotopic equilibrium is reached before or at 14 days of exchange (i.e. 165 that the fraction of radioactivity remaining in the solution has reached a constant 166 value), we can subtract the fraction of radioactivity remaining at equilibrium from 167 the $r_{t} / R$ values measured at earlier times during the experiment and analyze the 168 resulting curve. If a finite number of compartments can be identified it is possible to 169 separate the obtained curve in a sum of exponential terms that are a function of 170 exchange time. The final equation describing the change of radioactivity in solution 171 with time can then be written as follows:

$172 \frac{r_{t}}{R}=A+\sum_{i=1}^{N-1} B_{i} \times e^{-C_{i} \times t}$ 
173 Where $r_{\mathrm{t}} / R$ is the fraction of ${ }^{65} \mathrm{Zn}$ remaining in solution at the time of sampling, $A, B_{i}$

174 and $C_{i}$ are constants, $N$ is the total number of compartments.

175 The theory of the compartmental analysis states that when the system is

176 closed, at a steady-state for the element studied, and when the tracer (here ${ }^{65} \mathrm{Zn}$ ) is

177 introduced in one injection within a very short time, then the number of total

178 compartment $(N)$ is equal to the number of exponential terms $(N-1)$ plus 1 (Cobelli

179 et al., 2000).

180 This analysis suggests the presence in all soils of a compartment of $\mathrm{Zn}$

181 exchangeable during the first minute of exchange while other compartments differed

182 from soil to soil in their time limits and/or in their total numbers. To simplify the

183 subsequent analysis of the results we decided to consider only three pools of $\mathrm{Zn}$ (a

184 pool being defined as a group of compartments, Cobelli et al., 2000) in the rest of

185 the paper: the pool of $\mathrm{Zn}$ exchangeable within 1 minute which is observed in all

186 soils (pool 1), the pool of $\mathrm{Zn}$ that is exchangeable between 1 minute and apparent

187 isotopic equilibrium (pool 2) and the pool of $\mathrm{Zn}$ that can not be exchanged or that

188 exchanges very slowly (pool 3). The amount of $\mathrm{Zn}$ isotopically exchangeable within

189 a given time ( $E_{t}$ value, $\left.\mathrm{mg} \mathrm{kg}^{-1}\right)$ is calculated using the following equation:

$190 \quad E_{t}=\left[\left(\frac{v}{m}\right) \times C_{Z n}\right] \times \frac{R}{r_{t}}$

191 Where $v / m$ is the solution to soil ratio $\left(\mathrm{kg}^{-1}\right), C_{\mathrm{Zn}}$ is the $\mathrm{Zn}$ concentration $\left(\mathrm{mg}^{-1}\right)$ in

192 solution and $r_{\mathrm{t}} / R$ is the fraction of ${ }^{65} \mathrm{Zn}$ remaining in solution at the time $t$ of

193 sampling. The amount of $\mathrm{Zn}$ present in the pool $1\left(E_{\text {pool1 }}\right)$ is calculated considering

194 an exchange time of 1 minute, the amount of $\mathrm{Zn}$ present in the pool $2\left(E_{\text {pool2 }}\right)$ is the

195 difference between the amount of $\mathrm{Zn}$ that has been exchanged at apparent isotopic

196 equilibrium and the amount of $\mathrm{Zn}$ exchangeable within one minute. The amount of 
$197 \mathrm{Zn}$ present in the pool $3\left(E_{\text {pool3 }}\right)$ is calculated as the difference between soil total $\mathrm{Zn}$

198 and the amount of $\mathrm{Zn}$ that has been exchanged at apparent isotopic equilibrium.

Pot experiment with Thlaspi caerulescens, calculation of the L value

201 The most readily exchangeable $\mathrm{Zn}$ pools were labeled with carrier-free ${ }^{65} \mathrm{Zn}$ (NEN

202 Biosciences, Boston, USA; specific activity: $2.0 \mathrm{GBq} \mathrm{mg}^{-1} \mathrm{Zn}$ ). De-ionized water, nutrient solution and ${ }^{65} \mathrm{Zn}$ were mixed well in to the soils to bring the soil moisture content to $50 \%$ water holding capacity (WHC), to provide basal nutrients and to obtain an activity of $2.4 \mathrm{MBq} \mathrm{kg}^{-1}$ soil. The activity was raised to $4.7 \mathrm{MBq} \mathrm{kg}^{-1}$ soil in the Dornach soil due its high Zn fixing capacity. The nutrient solution provided

$207120 \mathrm{mg} \mathrm{K} \mathrm{kg}^{-1}$ dry soil as $\mathrm{K}_{2} \mathrm{SO}_{4}$ and $\mathrm{KH}_{2} \mathrm{PO}_{4}, 30 \mathrm{mg} \mathrm{Mg} \mathrm{kg}{ }^{-1}$ dry soil as $\mathrm{MgSO}_{4}$, $208140 \mathrm{mg} \mathrm{N} \mathrm{kg}^{-1}$ dry soil as $\mathrm{NH}_{4} \mathrm{NO}_{3}, 60 \mathrm{mg} \mathrm{P} \mathrm{kg}^{-1}$ dry soil as $\mathrm{KH}_{2} \mathrm{PO}_{4}$ and $58 \mathrm{mg} \mathrm{S}$ $209 \mathrm{~kg}^{-1}$ dry soil as $\mathrm{K}_{2} \mathrm{SO}_{4}$ and $\mathrm{MgSO}_{4}$. Incubation of the soils for 40 days at $21^{\circ} \mathrm{C}$ 210 under aerobic conditions was performed to allow the ${ }^{65} \mathrm{Zn}$ to label the most readily 211 exchangeable pools. Each pot was filled with $400 \mathrm{~g}$ dry mass soil and the water 212 content was raised to $75 \%$ water holding capacity (WHC) before sowing the seeds.

213 The pot experiment consisted of a randomized block design of four 214 replicates. Ten seeds of $T$. caerulescens (Ganges ecotype) were sown and after 215 germination $(\sim 14$ days $)$ the plants were thinned to four plants per pot. Pots were 216 watered daily with de-ionized water to maintain $75 \%$ soil WHC. The plants were 217 grown under a controlled environment of $16^{\circ} \mathrm{C} / 8 \mathrm{~h}$ night and $20^{\circ} \mathrm{C} / 16 \mathrm{~h}$ day, at $21870 \%$ relative humidity and a light intensity of $280 \mu \mathrm{mol} \mathrm{m} \mathrm{s}^{-1}$.

219 After 80 days growth, the plants were harvested by cutting shoots at the soil 220 surface. The plant aerial biomass was washed with de-ionized water, dried at $85^{\circ} \mathrm{C}$ 221 for 24 hours and the dry mass was measured. Plant $\mathrm{Zn}$ concentrations were obtained 
222 by grinding the plant material with an agate ball mill and using a dry-ash digestion 223 method adapted from Chapman and Pratt (1961). The method was performed by

224 incinerating a $1 \mathrm{~g}$ sample at $500^{\circ} \mathrm{C}$ for 8 hours, dissolving the residual ashes with 2 $225 \mathrm{ml}$ of $5.8 \mathrm{M}$ analytical grade $\mathrm{HCl}$ that was further diluted to $50 \mathrm{ml}$ with de-ionized 226 water before element and isotope measurements. Zn concentrations were determined 227 by ICP-OES (Varian Liberty 220) and ${ }^{65} \mathrm{Zn}$ was measured using high purity Ge 228 bore-hole gamma detector (EAWAG, Dübendorf, Switzerland). All ${ }^{65} \mathrm{Zn}$ 229 measurements were corrected back to the date of soil labeling.

230 Calculation of the $L$ value (mg $\mathrm{Zn} \mathrm{kg}$ soil ${ }^{-1}$ ) was performed with the 231 following equation proposed by Smith (1981):

$$
L=\frac{\left(Z n_{\text {plant }}-Z n_{\text {seed }}\right)}{\frac{{ }^{65} Z n_{\text {plant }}}{{ }^{65} Z n_{\text {introduced }}}}
$$

233 where $Z n_{\text {plant }}\left(\mathrm{mg} \mathrm{Zn}\right.$ plant $\left.^{-1}\right)$ is the amount of $\mathrm{Zn}$ in the aerial parts of the plant, $234 Z n_{\text {seed }}\left(\mathrm{mg} \mathrm{Zn} \mathrm{plant}{ }^{-1}\right)$ is the amount of $\mathrm{Zn}$ in the seed, ${ }^{65} \mathrm{Zn}_{\text {plant }}\left(\mathrm{Bq}\right.$ plant $\left.{ }^{-1}\right)$ is the 235 amount of ${ }^{65} \mathrm{Zn}$ in the aerial parts of the plant, and ${ }^{65} \mathrm{Zn}_{\text {introduced }}$ the total amount of $236{ }^{65} \mathrm{Zn}$ introduced to the soil $\left(\mathrm{Bq} \mathrm{kg}^{-1}\right.$ soil). This equation provides the most 237 conservative calculation of $L$ since it assumes that all the seed $\mathrm{Zn}$ was redistributed 238 to the aerial portions of the plant. The concentration of $\mathrm{Zn}$ present in the seeds $239\left(Z n_{\text {Seed }}\right)$ was $34.0 \mathrm{ng} \mathrm{Zn} \mathrm{plant}{ }^{-1}$ (standard error: $\left.0.1 \mathrm{ng} \mathrm{Zn} \mathrm{plant}{ }^{-1}\right)$.

Selective Sequential Extraction and Total Digestion

242 Before conducting the selective sequential extraction (SSE), soils were labeled with ${ }^{65} \mathrm{Zn}$ and incubated for 20,85 and 120 days at $21^{\circ} \mathrm{C}$. At the time of labeling, a

244 carrier-free ${ }^{65} \mathrm{Zn}$ solution (NEN Biosciences, Boston, USA; specific activity: 2.0 
$245 \mathrm{GBq} \mathrm{mg}{ }^{-1} \mathrm{Zn}$ ) was added as $\mathrm{ZnCl}_{2}$ to de-ionized water and mixed well with the soil 246 samples at the rate of 22.5 to $86.0 \mathrm{MBq} \mathrm{kg}^{-1}$ soil. Soils were maintained at $50 \%$

247 water holding capacity and well aerated during the incubation period.

248 The selective sequential extraction used in this study was a six-step 249 procedure (F1-F6) developed by Salbu et al. (1998) and modified using a 1:10 soil 250 to extractant ratio. A description of the analytical grade reagents, procedures and the 251 proposed binding mechanisms are provided in Table 2. The extraction procedure is 252 designed to extract metals in a step-wise fashion first from weak outer sphere bound 253 forms (F1-F3), then from tightly bound outer and inner sphere complexes (F4 and 254 F5) and finally from crystalline metal forms (F6). Prior to performing extractions, 255 the soil samples were ground to a fine powder to homogenize and increase the 256 surface area exposed to the extractants during the extraction process. For each 257 extraction step the samples were shaken on a horizontal shaker at $100 \mathrm{rpm}$ for the 258 times listed in the procedure. Following each extraction, the samples were 259 centrifuged at $11^{\prime} 000 \mathrm{~g}$ for 30 minutes, the solution was filtered through a $0.45 \mu \mathrm{m}$ 260 porosity filter and the filtrate was analyzed for $\mathrm{Zn}$ and ${ }^{65} \mathrm{Zn}$. Measurements for $\mathrm{Zn}$ were performed on an ICP-OES (Varian Liberty 220) and ${ }^{65} \mathrm{Zn}$ was measured using

262 high purity Ge bore-hole gamma detector (EAWAG, Dübendorf, Switzerland). All $263{ }^{65} \mathrm{Zn}$ measurements were corrected back to the date of soil labeling.

264 As a final step (F7), the F6 residue was placed in an open-vessel microwave 265 digester (MX 350 Prolabo, France) and the procedure of Lorentzen and Kingston 266 (1996) was used to extract the residual $\mathrm{Zn}$. After digestion, the sample was cooled to 267 room temperature filtered with a $0.45 \mu \mathrm{m}$ porosity filter prior to ICP-OES (Varian 268 Liberty 220) analysis. In addition, a single step total digestion was conducted on all 
269 soils to obtain total $\mathrm{Zn}$ and ${ }^{65} \mathrm{Zn}$ quantities as a comparison to the total quantities 270 recovered by the SSE.

271 The fraction of $\mathrm{Zn}$ that had undergone isotopic exchange in each fraction of

272 the SSE was assessed by calculating the specific activity (SA) of $\mathrm{Zn}$ in each fraction 273 normalized by the quantity of isotopes introduced during labeling ( ${ }^{65} Z n_{\text {introduced }} \mathrm{Bq}$

$274 \mathrm{~kg}^{-1}$ soil $)$ and the total soil $\mathrm{Zn}\left(Z n_{\text {total }} \mathrm{mg} \mathrm{Zn} \mathrm{kg}{ }^{-1}\right.$ soil $)$ as shown in equation 4.

275

$S A=\frac{\left(\frac{{ }^{65} Z n_{F_{X}}}{{ }^{65} Z n_{\text {introduced }}}\right)}{\left(\frac{Z n_{F x}}{Z n_{\text {total }}}\right)}$

276 In this equation the subscript $\mathrm{F}_{\mathrm{x}}$ is the extraction number, ${ }^{65} Z n_{\mathrm{Fx}}$ represents the 277 radioisotope concentration $\left(\mathrm{Bq} \mathrm{kg}{ }^{-1}\right.$ soil) in this extract and $Z n_{\mathrm{Fx}}$ the total $\mathrm{Zn}$ 278 concentration (mg Zn kg ${ }^{-1}$ soil) in the same extract.

280 Statistics

281 All soil analyses were conducted in triplicate while the plant analyses were made 282 with four replicates. Mean values are presented with the standard errors. 283 "Statgraphics plus for Windows" was used for both linear and nonlinear regressions. 284 The standard error of estimate (SEE) and the coefficient of determination are given 285 for each regression. The validity of regressions was evaluated by comparing the 286 predicted and experimental values and by looking at the residuals.

287

288 Extended X-ray Absorption Fine Structure (EXAFS) Spectroscopy 
289 Untreated reference samples of the Dornach and Mortagne soils and residues

290 obtained from the selective sequential extraction were air-dried at $35^{\circ} \mathrm{C}$ ground and 291 pressed into $5 \mathrm{~mm}$ diameter pellets for EXAFS analysis.

292 Experiments were conducted in 2003 at the European Synchrotron Radiation

293 Facility (ESRF, Grenoble, France) on beamline ID-26. The electron storage ring was

294 operating in 16 bunch mode at $6 \mathrm{GeV}$ and current ranging from 70 to $90 \mathrm{~mA}$. The

295 monochromator was a pair of $\operatorname{Si}(220)$ flat crystals. Spectra were collected in

296 fluorescence mode using a photo-diode detector and aluminum filters. For each

297 sample 10-20 scans of 40 minutes were averaged. Data extraction was done using

298 WinXAS (version 2.0, Ressler, 2000).

299 Data analysis was done by linear combination fits (LCFs) without principal 300 component analysis since this latter approach is not adapted to small sets of spectra.

301 The LCFs were conducted using a reference Zn K-edge reference spectra library 302 described previously (Manceau et al., 2003; Sarret et al., 2004). The maximum 303 number of components for the fit of the extraction residues and soil spectra was

304 limited to four since the precision of the method does not enable a reliable 305 quantification of more complex mixtures. From these four components, 306 concentrations of $\mathrm{Zn}$ species ( $\mathrm{mg} \mathrm{Zn} \mathrm{kg}^{-1}$ soil) in each sample were calculated by 307 multiplying the percentage of each component by the total $\mathrm{Zn}$ concentration in the 308 sample.

310 Results and discussion

311 Zn concentration in dilute $\mathrm{CaCl}_{2}$ extracts $\left(C_{Z n}\right)$

312 We present the average $C_{\mathrm{Zn}}$ values measured during the IE kinetic experiments for 313 each soil (Table 3). The highest values were observed in the Evin and Mortagne 
314 soils and the lowest values were observed in the IUL SS soil (Table 3). The

315 logarithm of $C_{\mathrm{Zn}}$ was highly significantly related to soil $\mathrm{pH}$ and to the logarithm of

316 the total soil $\mathrm{Zn}$ content of the 6 soils.

$317 \ln \left(C_{\mathrm{Zn}}\right)=4.81-3.06 p H+1.86 \ln \left(Z n_{\text {total }}\right), \mathrm{n}=6, \mathrm{R}^{2}=0.97, \mathrm{SEE}=0.67$

318 This result confirms that $C_{\mathrm{Zn}}$ increases with $\mathrm{Zn}$ inputs and decreases when soil $p H$

319 increases as noted by Arias et al. (2005). The very low $C_{\mathrm{Zn}}$ values observed in the

320 IUL SS soil can be explained by its high amorphous iron oxide content (Table 1)

321 acting as a strong sorbent for $\mathrm{Zn}$. The elevated amorphous iron oxide content of this

322 soil is related to the repeated additions of $\mathrm{FeCl}_{3}$ treated sewage sludge in this field

323 experiment.

Decrease of radioactivity in dilute $\mathrm{CaCl}_{2}$ extracts with time during the isotopic exchange kinetic experiments

327 The radioactivity found in the solution at a given time divided by the total amount of

328 radioactivity added to the suspension $\left(r_{t} / R\right)$ decreased following the same pattern in

329 all samples (Figure 1). In most soils the 2 last $r_{t} / R$ values were very similar showing 330 that an apparent isotopic equilibrium had been reached after 14 days. Only in the

331 IUL PS and in the Evin soils was the last $r_{t} / R$ value lower than the previous one

332 indicating that the isotopic equilibrium might have not been reached after 14 days of 333 IE.

334 It was possible to fit the curves describing the decrease of $r_{t} / R$ with exchange 335 time by the equation 1 by a sum of two exponential terms and a constant for the 336 Dornach soil and by a sum of three exponential terms and a constant for the other 337 soils (data not shown). These results suggest that the ${ }^{65} \mathrm{Zn}$ added in the solution 338 exchanged with $\mathrm{Zn}$ located in 3 compartments in the Dornach soil and in 4 
339 compartments in the other soils. These compartments corresponded to the following

340 exchange times: $0-1 \mathrm{~min}, 1-30 \mathrm{~min}, 30 \mathrm{~min}-7$ days and $>7$ days in INRA and IUL

$341 \mathrm{SS}$; 0-1 $\mathrm{min}, 1-10 \mathrm{~min}, 10 \mathrm{~min}$ to 14 days and $>14$ days in IUL PS; $0-1 \mathrm{~min}, 1-30$

$342 \min , 30 \min$ to 14 days and $>14$ days in Evin; $0-1$ min, 1 min to 1 day and $>1$ day

343 in Dornach; and 0-1 $\mathrm{min}, 1-30 \mathrm{~min}, 30 \mathrm{~min}$ to 7 days and $>7$ days in Mortagne.

344 Models with two exponential terms and a constant were tried for all soils but gave a

345 proper fit only for Dornach (results not shown). This analysis suggests the presence

346 in all soils of a compartment of $\mathrm{Zn}$ exchangeable during the first minute, while other

347 compartments differed from soil to soil.

348 This compartmental analysis has some limits and its results must be

349 interpreted with caution. More sampling points might have resulted in the 350 determination of more compartments (Fardeau, 1993). Besides, it is extremely

351 difficult to sample the suspension at exchange time shorter than 1 minute (Fardeau,

352 1993). The stochastic approach used by Sinaj et al. (1999) was tested with our soils.

353 This approach allowed modeling the changes of $r_{t} / R$ with time as well as the sum of

354 exponentials for all soils except for IUL PS where it led to negative values of

355 radioactivity as time tended towards the infinity (results not shown). Besides, this

356 stochastic approach does not allow distinguishing compartments of exchangeable

357 elements (Fardeau, 1993).

359 Calculation of the amount of isotopically exchangeable Zn (E values)

360 Because of the different number of compartments observed between soils we prefer

361 to summarize the information given by the compartmental analysis by considering

362 only three pools of exchangeable $\mathrm{Zn}$ for each soil: the amount of $\mathrm{Zn}$ exchangeable

363 within 1 minute which is observed in all soils (pool 1), the amount of $\mathrm{Zn}$ 
364 exchangeable that is exchangeable on the medium term (pool 2), and the amount of

$365 \mathrm{Zn}$ that is very slowly or not exchangeable (pool 3). The pool 2 corresponds to the

366 fraction of soil $\mathrm{Zn}$ that is exchangeable between 1 minute and apparent isotopic

367 equilibrium, i.e. between 1 minute and 1 day in Dornach, between 1 minute and 7

368 days in INRA, IUL SS and Mortagne, and between 1 minute and 14 days in IUL PS

369 and Evin. The pool 3 corresponds to the amount of $\mathrm{Zn}$ that could not be isotopically

370 exchanged within 1 day in Dornach, within 7 days in INRA, IUL SS and Mortagne

371 and within 14 days in Evin and IUL PS.

372 The amounts of $\mathrm{Zn}$ present in the $1^{\text {st }}, 2^{\text {nd }}$ and $3^{\text {rd }}$ pools $\left(E_{\text {pool1 }}, E_{\text {pool2 }}\right.$ and

$373 E_{\text {pool3 }}$ ) are presented in Table 3. Soils polluted with organic amendments (INRA,

374 IUL SS, IUL PS) had between 3.5 and $11.9 \%$ of the total $\mathrm{Zn}$ in the pool 1 and

375 between 68.1 and $78.9 \%$ of total $\mathrm{Zn}$ in the pool 3. The Evin and Mortagne smelter-

376 impacted soils had between 42.3 and $46.8 \%$ of the total $\mathrm{Zn}$ in the pool 1 and

377 between 39.1 and $39.9 \%$ of total $\mathrm{Zn}$ in the pool 3. The Dornach smelter-impacted

378 soil showed an intermediate result with $10.7 \%$ of $\mathrm{Zn}$ in the pool 1 and $67.5 \%$ in the

379 pool 3. Highly significant relationships were observed between the logarithm of the

380 Zn content of pool $1\left(E_{\text {pool1 }}\right)$ and pool $2\left(E_{\text {pool2 }}\right)$ and the logarithm of total $\mathrm{Zn}$ and $p H$

381 (equations 6 and 7).

$382 \ln \left(E_{\text {pool1 }}\right)=-0.51-1.03 p H+1.67 \ln \left(Z n_{\text {total }}\right), \mathrm{n}=6, \mathrm{R}^{2}=0.98, \mathrm{SEE}=0.39$

$383 \ln \left(E_{\text {pool } 2}\right)=-2.92+0.19 p H+1.03 \ln \left(Z n_{\text {total }}\right), \mathrm{n}=6, \mathrm{R}^{2}=0.98, \mathrm{SEE}=0.23$

384 These equations show that the amount of $\mathrm{Zn}$ present in the $1^{\text {st }}$ pool increases with $\mathrm{Zn}$

385 inputs and decreases with $\mathrm{pH}$, while the amount of $\mathrm{Zn}$ present in the $2^{\text {nd }}$ pool 386 increases with $\mathrm{Zn}$ inputs and $\mathrm{pH}$.

388 Pot experiment with T. caerulescens, calculation of the $L$ value 
389 The results are presented in Table 4. The biomass production of $T$. caerulescens was 390 similar in all soils, but the $\mathrm{Zn}$ content in the plant increased with soil total $\mathrm{Zn}$

391 content. The $L$ values varied between 22.2 and $32.9 \%$ of the total soil $\mathrm{Zn}$ content in

392 the three soils that had been polluted by organic amendments and between 33.4 and

$39356.4 \%$ of the total soil $\mathrm{Zn}$ content in the three soils that had been polluted by smelter

394 emissions. The $L$ values were numerically very similar to the sum of the $\mathrm{Zn}$ content 395 present in the 2 first pools of the isotope exchange kinetic analysis (equations 8 and 396 9).

$397 \ln (L)=0.13+0.97 \ln \left(E_{\text {pool1 }}+E_{\text {pool } 2}\right), \mathrm{n}=6, \mathrm{R}^{2}=0.99, \mathrm{SEE}=0.08$

$398 \ln \left(E_{\text {pool1 }}+E_{\text {pool } 2}\right)=-0.12+1.03 \ln (L), \mathrm{n}=6, \mathrm{R}^{2}=0.99, \mathrm{SEE}=0.08$

399 This result shows that pools 1 and 2 contain the soil $\mathrm{Zn}$ that can be accessed by $T$. 400 caerulescens through diffusion and desorption.

401

402 Selective sequential extraction of ${ }^{65} \mathrm{Zn}$ and $\mathrm{Zn}$ from incubated soil

403 No significant shifts in ${ }^{65} \mathrm{Zn}$ concentration between the extracted fractions were 404 noted for all soils between 20, 85 and 120 days of incubation, with the exception of 405 the Evin and Mortagne soils in which ${ }^{65} \mathrm{Zn}$ concentrations significantly decreased in 406 F2 while the concentration of ${ }^{65} \mathrm{Zn}$ increased in F3 and F4. This coincides with the 407 findings of Almås et al. $(1999,2000)$ in which measurable levels of ${ }^{65} \mathrm{Zn}$ were found 408 among all fractions within 7 days of soil labeling.

409 The normalized specific activities observed for each fraction are presented in

410 Table 6. A monotonous decrease down to null activities was expected from the most 411 exchangeable (F1) to the residual (F7) fraction. However, the specific activities 412 values obtained in F1 were often lower than in F2. We suggest that the relatively 413 low $\mathrm{Zn}$ and ${ }^{65} \mathrm{Zn}$ concentrations extracted by the water (F1) and their high variability 
414 might explain the difficulties in calculating correct specific activities values. If we

415 do not consider F1, a monotonous decrease is observed from F2 to F7, except for the

416 F3 extraction for the Evin and Mortagne soils. The activity is very low in the F6

417 extract and close to 0 in the F7 residual, as expected. This ${ }^{65} \mathrm{Zn}$ tracing of the SSE

418 confirms that the chosen extractants induced a progressive removal of $\mathrm{Zn}$ from

419 highly exchangeable to recalcitrant species.

420 The average concentrations of $\mathrm{Zn}$ in the different fractions of the SSE are

421 provided in Table 5. The total amount of $\mathrm{Zn}$ recovered from this sequential 422 extraction ranged between 90.9 and $116 \%$ of the total $\mathrm{Zn}$ content measured after 423 direct digestion. Between 41.0 and $49.6 \%$ of the total $\mathrm{Zn}$ was extracted in the $6^{\text {th }}$ 424 step (F6) in INRA, IUL SS and IUL PS soils while in the Evin and Mortagne soils 425 between 45.4 and $53.6 \%$ of the $\mathrm{Zn}$ was extracted in the $2^{\text {nd }}$ and $3^{\text {rd }}$ steps $(\mathrm{F} 2-\mathrm{F} 3$ 426 fractions). This predominance of exchangeable species is most likely due to the 427 dissolution of smelter-inherited primary minerals (franklinite, sphalerite, willemite) 428 and redistribution in the exchangeable fractions as described by various authors 429 (Juillot et al, 2003, Manceau et al., 2000, Roberts et al., 2002).

430 Comparison between the amounts of $\mathrm{Zn}$ recovered in the different fractions 431 of the SSE (Table 5) and the amount of isotopically exchangeable $\mathrm{Zn}$ (Table 3), 432 shows that the total amount of $\mathrm{Zn}$ extracted during the 3 first steps $\left(Z n_{\mathrm{F} 1+\mathrm{F} 2+\mathrm{F} 3}\right)$ is 433 slightly higher than the amount of very rapidly exchangeable $\mathrm{Zn}\left(E_{\text {pool1 }}\right)$ (equations 43410 and 11).

$435 \ln \left(Z n_{\mathrm{F} 1+\mathrm{F} 2+\mathrm{F} 3}\right)=0.78+0.92 \ln \left(E_{\mathrm{pool} 1}\right), \mathrm{n}=6, \mathrm{R}^{2}=0.97, \mathrm{SEE}=0.38$

$\ln \left(E_{\mathrm{pool} 1}\right)=-0.68+1.05 \ln \left(Z n_{\mathrm{F} 1+\mathrm{F} 2+\mathrm{F} 3}\right), \mathrm{n}=6, \mathrm{R}^{2}=0.97, \mathrm{SEE}=0.40$

437 This suggests that these 3 first steps have extracted the entire quantity of $\mathrm{Zn}$ 438 isotopically exchangeable within 1 minute, and that F3 extracted a fraction of the $\mathrm{Zn}$ 
439 exchangeable on the medium term. Highly significant correlations were also found

440 between $\ln \left(Z n_{\mathrm{F} 5+\mathrm{F} 6+\mathrm{F} 7}\right)$ and $\ln \left(E_{\mathrm{pool} 3}\right)$ (equations 12 and 13$)$.

$441 \ln \left(Z n_{\mathrm{F} 5+\mathrm{F} 6+\mathrm{F} 7}\right)=1.20+0.73 \ln \left(E_{\mathrm{pool} 3}\right), \mathrm{n}=6, \mathrm{R}^{2}=0.87, \mathrm{SEE}=0.35$

$442 \ln \left(E_{\mathrm{pool} 3}\right)=-0.65+1.19 \ln \left(Z n_{\mathrm{F} 5+\mathrm{F} 6+\mathrm{F} 7}\right), \mathrm{n}=6, \mathrm{R}^{2}=0.87, \mathrm{SEE}=0.44$

443 The lower amount of $\mathrm{Zn}$ recovered in $\mathrm{F} 5+\mathrm{F} 6+\mathrm{F} 7$ compared to $E_{\text {pool3 }}$ suggests that a

444 fraction of very slowly or not exchangeable $\mathrm{Zn}$ had already been extracted in F4.

445 Since F1+F2+F3 extracted the $\mathrm{Zn}$ present in the pool 1 and some of the $\mathrm{Zn}$ present

446 in pool 2 and F5+F6+F7 extracted a fraction of the pool 3, we conclude that the $4^{\text {th }}$

447 step of the SSE solubilized both moderately and slowly exchangeable forms of $\mathrm{Zn}$,

448 i.e. $\mathrm{Zn}$ from pools 2 and 3.

Zn K-edge EXAFS spectroscopy

451 Zinc K-edge EXAFS analysis was conducted on the Dornach and Mortagne

452 untreated samples and on the F2 and F3 residues for the Mortagne soil, and the F3,

$453 \quad$ F4 and F5 residues for the Dornach soil.

454 Figure 2 shows the Zn K-edge EXAFS spectra for some reference 455 compounds used in the linear combination fits, including franklinite, Zn-sorbed 456 birnessite (Mn oxide), Zn-substituted kerolite as a proxy for $\mathrm{Zn}$-substituted 457 phyllosilicate, Zn/Al hydrotalcite, a zinc-aluminum hydroxycarbonate, Zn-sorbed 458 ferrihydrite, Zn-humic acid complexes (Zn-HA) at high and low $\mathrm{Zn}$ loading, and 459 aqueous $\mathrm{Zn}^{2+}$ as a proxy for outer sphere complexes. Franklinite is easily identified 460 by the high amplitude and multiple frequencies of its spectrum. The spectra for $\mathrm{Zn}$ 461 kerolite and $\mathrm{Zn} / \mathrm{Al}$ hydrotalcite present some similarities, which makes their 462 distinction difficult in a mixture (Panfili et al., 2005). In the LCFs, these two 463 compounds and Zn-sorbed hectorite were grouped as "Zn-phyllosilicate". Similarly, 
464 the spectra for Zn-HA at low Zn loading and Zn-sorbed ferrihydrite look similar

465 because $\mathrm{Zn}$ is 4-fold coordinated to oxygen atoms and the second shell contribution

466 weak in the two references. $\mathrm{Zn}-\mathrm{HA}$ at low $\mathrm{Zn}$ loading is a proxy for strongly bound

467 inner sphere Zn-organic complexes in tetrahedral configuration (Sarret et al., 1997).

468 In the LCFs, the two tetrahedral species were grouped as "tetrahedral Zn-HA and/or

469 Zn-sorbed ferrihydrite". Another pair of similar spectra is Zn-HA at high Zn loading

470 and aqueous $\mathrm{Zn}^{2+}$ Because $\mathrm{Zn}$ is octahedrally coordinated, and the second shell

471 contribution either weak ( $\mathrm{Zn}-\mathrm{HA})$ or absent (aqueous $\mathrm{Zn}$ ). These species are

472 considered as representatives for less-strongly to weakly bound inner sphere $\mathrm{Zn}$ -

473 organic complexes and outer sphere organic and inorganic complexes (Sarret et al.,

474 1997). In the LCFs, these species were grouped as "weakly bound octahedral Zn".

475 Figure 3a shows the EXAFS spectra for the untreated soil from Mortagne

476 and the two residues, and their reconstructions with four component spectra. In the

477 untreated soil (MRef), $\mathrm{Zn}$ is distributed as $60 \pm 10 \%$ weakly bound octahedral $\mathrm{Zn}$

478 complexes, $17 \pm 10 \%$ Zn-phyllosilicate, $16 \pm 10 \%$ tetrahedral Zn-HA and/or Zn-

479 sorbed ferrihydrite and 7\% franklinite (Figure 3b). The detection limit for this last

480 species is less than $10 \%$ because its spectrum has a high amplitude. Zn-sorbed

481 goethite and Zn-sorbed hematite spectra were tested, but neither of them are

482 component species to the data. In a previous study on the same soil (Manceau et al.,

483 2000), Zn- phyllosilicate, Zn-sorbed birnessite and Zn sorbed on iron oxyhydroxides

484 were identified as the main $\mathrm{Zn}$ species. Another study on a tilled soil near the

485 Mortagne area concluded to the presence of $\mathrm{Zn}$ outer-sphere complexes, Zn-organic

486 matter inner-sphere complexes, Zn/Al-hydrotalcite, Zn-phyllosilicate, and

487 magnetite-franklinite solid solutions (Juillot et al., 2003). The F2 extraction

488 removed $41 \%$ of the soil $\mathrm{Zn}$, and most of the weakly bound octahedral $\mathrm{Zn}$ pool. The 
489 F3 extraction removed $15 \%$ of the initial soil $\mathrm{Zn}$, the rest of the weakly bound pool, 490 and some of the tetrahedral pool. The Zn-phyllosilicate and franklinite pools were 491 marginally affected. The occurrence of $10-14 \% \mathrm{Zn}$ as franklinite in the MF2 and 492 MF3 samples is attested by the sharpening of the second oscillation centered at $6 \AA^{-}$ 493 1. In this soil the F2 and F3 extractions are relatively specific, affecting mostly the 494 weakly bound octahedral Zn pool.

In this soil the weakly bound octahedral $\mathrm{Zn}$ measured in the untreated sample (784 $\mathrm{mg} \mathrm{Zn} \mathrm{kg}^{-1}$ soil) was identical to the IE exchangeable $\mathrm{Zn}\left(E_{\mathrm{pool1}}+E_{\text {pool2 }}\right.$,

$497786 \mathrm{mg} \mathrm{Zn} \mathrm{kg}^{-1}$ soil) and to the amount of Zn extracted by the three first steps of the 498 SSE (F1+F2+F3, $729 \mathrm{mg} \mathrm{Zn} \mathrm{kg}^{-1}$ soil) (Table 7). These observations suggest that 499 weakly bound octahedral $\mathrm{Zn}$ is the main source of available $\mathrm{Zn}$ in this soil which is 500 consistent with our previous EXAFS and isotopic exchange study (Sarret et al., $5012004)$.

502 A different behavior is observed for the Dornach soil (Figure 4). Satisfactory 503 fits were obtained with three components for the untreated soil (DRef) and F3 and 504 F4 residues (DF3 and DF4), and with four components for the F5 residue (DF5). 505 The weakly bound octahedral $\mathrm{Zn}$ are predominant in the Dornach soil $(57 \pm 10 \%)$ 506 followed by Zn-phyllosilicate (27 $\pm 10 \%$ ), and tetrahedral Zn-HA and/or Zn-sorbed 507 ferrihydrite $(16 \pm 10 \%)$. The proportions of $\mathrm{Zn}$ species did not change statistically 508 in DF3 and DF4, which suggests that all species were affected to a similar extent by 509 the F3 and F4 treatments (removal of 19 and $41 \%$ of total soil $\mathrm{Zn}$, respectively). 510 The F5 extraction (removal of 19\% total soil Zn) targeted preferentially the "weakly 511 bound octahedral $\mathrm{Zn}$ " pool. As a consequence, Zn-phyllosilicate was the major 512 species in the DF5 residue. The DF5 spectrum was simulated with Zn-hectorite, 513 whereas DRef, DF3 and DF4 were simulated with Zn-kerolite and/or Zn/Al 
514 hydrotalcite. Indeed, the third oscillation of the DF5 and Zn-hectorite spectra have

515 the same shape, whereas the shoulder between 7.0 and $7.5 \AA^{-1}$ in DRef corresponds

516 to a high amplitude feature in Zn-kerolite and/or Zn/Al hydrotalcite spectra (Figures

5172 and $4 \mathrm{a}$ ). Therefore, the local environment of $\mathrm{Zn}$ seems to have evolved during the

518 selective sequential extraction. A finer description of the nature and structure of

519 these species would require studying the $<2 \mu \mathrm{m}$ or $<0.2 \mu \mathrm{m}$ soil fractions by

520 polarized EXAFS (Manceau et al., 2000). A new species is detected in DF5, Zn-

521 sorbed birnessite. This species was probably present in the previous samples

522 including those from Mortagne as shown by micro-EXAFS (Manceau et al., 2000),

523 but as a minor component masked by the predominant species. Chemical extractions

524 lacked selectivity in the Dornach soil because the fractional amount of the major 525 species remained unchanged in DF3 and DF4 despite a removal of 19 and $41 \%$ of

526 the soil $\mathrm{Zn}$. The weakly bound octahedral $\mathrm{Zn}$ complexes which were extracted

527 completely after the third extraction step in Mortagne soil remained predominant in

528 DF3 and DF4.

529 In Dornach the weakly bound octahedral $\mathrm{Zn}$ measured in the untreated 530 sample (962 $\mathrm{mg} \mathrm{Zn} \mathrm{kg}^{-1}$ soil) was similar to the $\mathrm{Zn}$ extracted by the four first steps 531 of the SSE (F1+F2+F3+F4, $1023 \mathrm{mg} \mathrm{Zn} \mathrm{kg}^{-1}$ soil), but was much higher than the IE 532 exchangeable $\mathrm{Zn}\left(E_{\text {pool1 }}+E_{\text {pool2 }}, 549 \mathrm{mg} \mathrm{Zn} \mathrm{kg}^{-1}\right.$ soil $)$, which itself was also higher 533 than the amount of Zn extracted by the three first steps of the SSE (F1+F2+F3, 326 $534 \mathrm{mg} \mathrm{Zn} \mathrm{kg}{ }^{-1}$ soil) (Table 7). Although Dornach exhibited a high proportion of 535 weakly bound octahedral Zn, only a small proportion of it was extracted by the 3 536 first extractions of the SSE (22\%). We suggest that the IE Zn and the Zn extracted 537 by the 3 first steps of the SSE was indeed present as weakly bound octahedral Zn, 538 but a large fraction of these so-called weakly bound species were neither IE 
539 exchangeable nor extractable by the three first steps of the SSE. The different

540 behavior of $\mathrm{Zn}$ in Dornach and Mortagne may be explained by the difference in soil

$541 \mathrm{pH}$ (6.7 for Dornach and 5.1 for Mortagne) and in soil organic matter content (11\%

542 for Dornach and 1\% for Mortagne) because inner-sphere mineral surface complexes

543 and organically-bound cationic species are more strongly retained at near neutral

544 than at acidic $\mathrm{pH}$. Altogether these results suggest that isotopically exchangeable $\mathrm{Zn}$

545 and therefore available $\mathrm{Zn}$ is present as weakly bound octahedral $\mathrm{Zn}$ species but that

546 the proportion of weakly bound octahedral $\mathrm{Zn}$ that can exchange with $\mathrm{Zn}^{2+}$ in the

547 solution decreases when soil $\mathrm{pH}$ and organic matter content increase.

549 Conclusion

550 The combination of techniques used in this work (isotopic exchange kinetics, pot

551 experiment with $T$. caerulescens on soil labeled with ${ }^{65} \mathrm{Zn}$, selective sequential 552 extraction carried out on ${ }^{65} \mathrm{Zn}$ labeled soils, and EXAFS spectroscopy) gave 553 comprehensive information on the forms and availability of $\mathrm{Zn}$ in these heavy metal 554 polluted soils. The main results of this study are summarized in the Table 7.

555 Our results allowed quantifying the number of compartments containing IE

$556 \mathrm{Zn}$ in these soils. Three pools were derived from this analysis, the amount of $\mathrm{Zn}$

557 exchangeable within 1 minute ( $1^{\text {st }}$ pool), the amount of $\mathrm{Zn}$ exchangeable between 1

558 minute and apparent isotopic equilibrium $\left(2^{\text {nd }}\right.$ pool $)$ and the amount of $\mathrm{Zn}$ that could

559 not be exchanged during the IE kinetic experiment $\left(3^{\text {rd }}\right.$ pool). The experiment

560 conducted with $T$. caerulescens confirmed that the amount of IE $\mathrm{Zn}$ measured in pot

561 experiments was similar to the sum of $\mathrm{Zn}$ content present in the $1^{\text {st }}$ and $2^{\text {nd }}$ pools, i.e.

562 that this plant had only access the IE forms of Zn. 
564 (F1, F2 and F3) solubilized the amount of $\mathrm{Zn}$ present in the $1^{\text {st }}$ pool and a slight

565 fraction of the $\mathrm{Zn}$ present in the $2^{\text {nd }}$ pool. The three last fractions of the SSE (F5, F6

566 and F7) solubilized the $\mathrm{Zn}$ from the $3^{\text {rd }}$ pool. We deduced from these observations

567 that the $4^{\text {th }}$ extraction of the SSE solubilized the $\mathrm{Zn}$ from the $2^{\text {nd }}$ pool and a fraction 568 of the $\mathrm{Zn}$ from the $3^{\text {rd }}$ pool.

569 Finally, EXFAS spectroscopy showed that the 3 first extractions of the SSE

570 solubilized all the weakly bound octahedral $\mathrm{Zn}$ in the Mortagne soil, i.e. that the $1^{\text {st }}$

571 pool was dominated by these $\mathrm{Zn}$ species. In Dornach the 5 first extractions of the

572 SSE were necessary to solubilize the weakly bound octahedral Zn. We suggest that

573 in Dornach most of the weakly bound octahedral Zn was not IE nor extractable in

574 the 3 first steps of the SSE. The difference between Mortagne and Dornach could

575 be explained by the highest $\mathrm{pH}$ and soil organic matter content of the latter.

576 Altogether these results suggest that isotopically exchangeable $\mathrm{Zn}$ and therefore

577 available $\mathrm{Zn}$ is present as weakly bound octahedral $\mathrm{Zn}$ species but that the

578 proportion of weakly bound octahedral $\mathrm{Zn}$ that can exchange with $\mathrm{Zn}^{2+}$ in the

579 solution decreases when soil $\mathrm{pH}$ and organic matter content increase.

580

581 Acknowledgements

582 We thank R. Kretzschmar (ETH Zürich) for providing samples of the Dornach and 583 Evin soils, F. van Oort (INRA Versailles) for contributing the Mortagne soil, T.

584 Rösch for her measurements on the ICP, E. Grieder (EAWAG, Dübendorf) for his 585 many hours of gamma measurements, M. Lanson for the preparation of Zn-HA 586 complexes, N. Geoffroy for his help during the EXAFS measurements, the kind 587 support of the staff at beam line ID-26, ESRF (Grenoble) and two anonymous 
588 reviewers for their constructive remarks. This study was made possible by beam

589 time granted through the European Synchrotron Radiation Facility (ESRF) and

590 funding from the research commission of the ETH, Zürich (TH project $\mathrm{n}^{\circ} 8086$ ).

591

592 References

593 Ahnstrom, Z.A.S. \& Parker, D.R. 2001. Cadmium reactivity in metal contaminated-

594 soils using a coupled stable isotope dilution-sequential extraction procedure.

595 Environmental Science \& Technology, 35, 121-126.

596 Almås, Å.R., Salbu, B. \& Singh, B.R. 2000. Changes in partitioning of cadmium-

$597 \quad 109$ and zinc-65 in soil as affected by organic matter addition and

598 temperature. Soil Science Society of America Journal, 64, 1951-1958.

599 Almås, Å.R., Singh, B.R. \& Salbu, B. 1999. Mobility of cadmium-109 and zinc-65

600 in soil influenced by equilibration time, temperature, and organic matter.

601 Journal of Environmental Quality, 28, 1742-1750.

602 Arias, M., Pérez-Novo, C., Osorio, F., Lopez, E. \& Soto, B. 2005. Adsorption and

603 desorption of copper and zinc in the surface layer of acid soils. Geoderma,

$604 \quad 288,21-29$.

605 Ayoub, A.S., McGaw, B.A., Shand, C.A. \& Midwood, A.J. 2003. Phytoavailability

606 of $\mathrm{Cd}$ and $\mathrm{Zn}$ in soil estimated by stable isotope exchange and chemical

607 extraction. Plant and Soil, 252, 291-300.

608 Cardellicchio, N., Cavalli, S., Ragone, P. \& Riviello, J.M. 1999. New strategies for

609 determination of transition metals by complexation ion-exchange

610 chromatography and post column reaction. Journal of Chromatography A,

$611 \quad \mathbf{8 4 7 ,} 251-259$. 
612 Chapman, H. D. \& Pratt, P. F. 1961. Methods of analysis for soils, plants, and

613 waters, pp. 169-170. University of California, Division of Agriculture

614 Sciences, Riverside, CA, USA.

615 Cobelli, C., Foster, D. \& Toffolo, G. 2000. Tracer Kinetics in Biomedical Research 616 from Data to Model. Kluwer Academic, Plenum Publishers, New York.

617 Degryse, F., Broos, K., Smolders, E. \& Merckx, R. 2003. Soil solution

618 concentration of $\mathrm{Cd}$ and $\mathrm{Zn}$ can be predicted with a $\mathrm{CaCl}_{2}$ soil extract.

619 European Journal of Soil Science, 54, 149-157.

620 FAL, RAC \& FAW. 1996. Schweizerische Referenzmethoden der Eidgenössischen 621 Forschungsanstalten, Band 1-4. Eidgenössischen Forschungsanstalten FAL, 622 RAC and FAW, Zürich, Changins, Wädenswil, Switzerland

623 Fardeau, J.C. 1993. Le phosphore assimilable des sols: sa représentation par un 624 modèle fonctionnel à plusieurs compartiments. Agronomie, 13, 317-331.

625 Geiger, G., Federer, P. \& Sticher, H. 1993. Reclamation of Heavy-Metal 626 Contaminated Soils - Field Studies and Germination Experiments. Journal of Environmental Quality, 22, 201-207.

628 Juillot, F., Morin, G., Ildefonse, P., Trainor, T.P., Benedetti, M., Galoisy, L., Calas,

629 G. \& Brown, G.E. 2003. Occurrence of $\mathrm{Zn} / \mathrm{Al}$ hydrotalcite in smelter-

630 impacted soils from northern France: Evidence from EXAFS spectroscopy

631 and chemical extractions. American Mineralogist, 88, 509-526.

632 Laboratoire de Spectrochimie Infrarouge et Raman (LASIR). 2000. Rapport d'activités 1997-2000. Université des Sciences et Technologies de Lille, $634 \quad$ Villeneuve d'Ascq, France p57. 
635 Loeppert, R.L. \& Inskeep, W.P. 1996. Iron. In: Methods of soil analysis. Part 3.

636 Chemical Methods (ed. P.J. Sparks), pp. 639-664. SSSA Book Series: 5.

637 SSSA, Madison, Wisconsin.

638 Lorentzen, E.M.L. \& Kingston, H.M. 1996. Comparison of microwave-assisted and 639 conventional leaching using EPA method 3050B. Analytical Chemistry, 68, $640 \quad 4316-4320$.

641 Manceau, A., Marcus, M. A. \& Tamura N. 2002. Quantitative speciation of heavy 642 metals in soils and sediments by synchrotron X-ray techniques. In 643 Applications of Synchrotron Radiation in Low-Temperature Geochemistry 644 and Environmental Science, Vol. 49 (eds. P. Fenter, M. Rivers, N. Sturchio, 645 \& S. Sutton), pp. 341-428. Reviews in Mineralogy and Geochemistry, 646 Mineralogical Society of America. Washington DC.

647 Manceau, A., Lanson, B., Schlegel, M.L., Harge, J.C., Musso, M., Eybert-Berard, 648 L., Hazemann, J.L., Chateigner, D. \& Lamble, G.M. 2000. Quantitative Zn 649 speciation in smelter-contaminated soils by EXAFS spectroscopy. American $650 \quad$ Journal of Science, 300, 289-343.

651 Manceau, A., Tamura, N., Celestre, R.S., MacDowell, A. A., Geoffroy, N., Sposito, 652 G. \& Padmore, H.A. 2003. Molecular-scale speciation of $\mathrm{Zn}$ and Ni in soil 653 ferromanganese nodules from loess soils of the Mississippi basin. $654 \quad$ Environmental Science \& Technology, 37, 75-80.

655 Nolan, A.L., Zhang, H. \& McLaughlin, M.J. 2005. Prediction of Zinc, Cadmium, 656 Lead, and Copper availability to wheat in contaminated soils using chemical 657 speciation, diffusive gradients in thin films, extraction, and isotopic dilution 658 techniques. Journal of Environmental Quality, 34, 496-507. 
659 Panfili, F.R., Manceau, A., Sarret, G., Spadini, L., Kirpichtchikova, T., Bert, V., 660 Laboudigue, A., Marcus, M.A., Ahamdach, N. \& Libert, M.F. 2005. The 661 effect of phytostabilization on $\mathrm{Zn}$ speciation in a dredged contaminated 662 sediment using scanning electron microscopy, X-ray fluorescence, EXAFS spectroscopy, and principal components analysis. Geochimica et

665 Ressler, T. 2000. WinXAS version 2.0. Livermore, CA, USA.

666 Roberts, D.R., Scheinost, A.C. \& Sparks, D.L. 2002. Zinc speciation in a smelter667 contaminated soil profile using bulk and microspectroscopic techniques. 668 Environmental Science \& Technology, 36, 1742-1750.

669 Salbu, B., Krekling, T. \& Oughton, D.H. 1998. Characterisation of radioactive 670 particles in the environment. Analyst, 123, 843-849.

671 Sarret, G., Balesdent, J., Bouziri, L., Garnier, J., Marcus, M., Geoffroy, N., Panfili, 672 F. \& Manceau, A. 2004. Zn speciation in the organic horizon of a contaminated soil by micro X-ray fluorescence, micro and powder EXAFS spectroscopy and isotopic dilution. Environmental Science \& Technology,

676 Sarret, G., Manceau, A., Hazemann, J.L., Gomez A. \& Mench, M. 1997. EXAFS study of the nature of zinc complexation sites in humic substances as a

679 Scheinost, A.C., Kretzschmar, R. \& Pfister, S. 2002. Combining selective sequential 680 extractions, x-ray absorption spectroscopy, and principal component analysis 681 for quantitative zinc speciation in soil. Environmental Science \& Technology, 36, 5021-5028. 
683 Schlegel, M. L., Manceau, A., Charlet, L., Chateigner D. \& Hazemann, J. L. 2001.

684 Sorption of metal ions on clay minerals. III. Nucleation and epitaxial growth

685 of Zn phyllosilicate on the edges of hectorite. Geochimica Et Cosmochimica $686 \quad$ Acta 65 (22), 4155-4170.

687 Schlegel, M.L. \& Manceau, A. 2006. Evidence for the nucleation and epitaxial 688 growth of Zn phyllosilicate on montmorillonite. Geochimica Et $689 \quad$ Cosmochimica Acta, 70, 901-917.

690 Siegenthaler, A., Häni, H. \& Stauffer, W. 1999. Effect of high sewage sludge and $691 \quad$ pig slurry application. Agrarforschung, 6(5), 1-8.

692 Sinaj, S., Mächler, F. \& Frossard, E. 1999. Assessment of isotopically exchangeable 693 zinc in polluted and nonpolluted soils. Soil Science Society of America 694 Journal, 63, 1618-1625.

695 Sinaj, S., Dubois, A. \& Frossard, E. 2004. Soil isotopically exchangeable zinc: a 696 comparison between E and L values. Plant and Soil, 261, 17-28.

697 Smith, F. W. 1981. Availability of soil phosphate to tropical pasture species. In: 698 Proceedings of XIV International Grassland Congress Lexington, KY USA (ed. by A. J. Smith \& V. W. Hays). Westview press, Bolder, CO USA.

700 Thiry, M., Huet-Taillanter, S. \& Schmitt, J.M. 2002. The industrial waste land of Mortagne-du-Nord (59) - I - Assesment, composition of the slags,

704 Weissenhorn, I., Mench, M. \& Leyval, C. 1995. Bioavailability of Heavy-Metals 705 and Arbuscular Mycorrhiza in a Sewage-Sludge-Amended Sandy Soil. Soil Biology \& Biochemistry, 27, 287-296. 
707 Young, S.D., Tye, A., Carstensen, A., Resende, L. \& Crout, N. 2000. Methods for 708 determining labile cadmium and zinc in soil. European Journal of Soil 709 Science, 51 (1), 129-136

710 Young, S.D., Zhang, H., Tye, A.M., Maxted, A., Thums, C. \& Thorton, I. 2006.

711 Characterizing the availability of metals in contaminated soils. I. The solid

712 phase: sequential extraction and isotopic dilution. Soil Use and Management, $713 \quad 21,450-458$ 


\section{$714 \quad$ Figure Captions}

715 Figure 1 Change in the fraction of radioactivity remaining in solution $\left(r_{t} / R\right)$ during

71614 days in six soils that have been polluted with heavy metals (1a INRA soil, $1 \mathrm{~b}$

717 IUL SS soil, 1c IUL PS soil, 1d Evin soil, 1e Dornach soil, 1f Mortagne soil). The

718 points represent the experimental data, the solid line the values predicted from the 719 model developed for each soil, and the dotted lines the $80 \%$ confidence limits of the 720 model.

721

722 Figure 2 Zn K-edge EXAFS spectra $\left(\chi(k) k^{3}\right.$, with $k$ : wave number) of reference $\mathrm{Zn}$ 723 compounds used to model the spectra for the soils and extraction residues:

724 Franklinite $\left(\mathrm{ZnFe}_{2} \mathrm{O}_{4}\right), \mathrm{Zn}$-sorbed birnessite (adsorption at $\mathrm{pH} 4, \mathrm{Zn} / \mathrm{Mn}=0.134$ )

725 (Manceau et al., 2000), Zn-substituted phyllosilicate ((Zn, Mg) kerolite $726 \mathrm{Zn}_{2.1} \mathrm{Mg}_{0.9} \mathrm{Si}_{4} \mathrm{O}_{10}(\mathrm{OH})_{2}, \mathrm{nH}_{2} \mathrm{O}$, Schlegel and Manceau, 2006 and $\mathrm{Zn}$-substituted 727 hectorite, Schlegel et al., 2001), $\mathrm{Zn} / \mathrm{Al}$ hydrotalcite $\left(\mathrm{Zn}_{2} \mathrm{Al}(\mathrm{OH})_{6}\left(\mathrm{CO}_{3}\right)_{0.5}, \mathrm{n} \mathrm{H}_{2} \mathrm{O}\right)$, 728 Zn-sorbed ferrihydrite containing $1500 \mathrm{mg} \mathrm{kg}^{-1} \mathrm{Zn}$ (Manceau et al., 2000), Zn729 humic acid complexes at low $\left(600 \mathrm{mg} \mathrm{kg}^{-1} \mathrm{Zn}\right)$ and high $(3.2 \% \mathrm{Zn}) \mathrm{Zn}$ loading 730 (Sarret et al., 1997), and aqueous $\mathrm{Zn}(\mathrm{pH} 4)$.

732 Figure 3 a) Zn K-edge EXAFS spectra (solid line) and linear combination fit

733 (dashed line) for the Mortagne untreated reference soil (MRef), for the residue left 734 after the second (MF2) and third (MF3) extraction of the SSE. b) Distribution of Zn 735 species derived from the fits. The error bars correspond to $10 \%$ of total $\mathrm{Zn}$ content.

737 Figure 4 a) Zn K-edge EXAFS spectra (solid line) and linear combination fits

738 (dashed line) for the Dornach untreated reference soil (DRef), for the residue left 
739 after the third (DF3), fourth (DF4) and fifth (DF5) extraction of the SSE. b)

740 Distribution of $\mathrm{Zn}$ species derived from the fits. The error bars correspond to $10 \%$ of 741 total $\mathrm{Zn}$ content. 
742 Figure 1

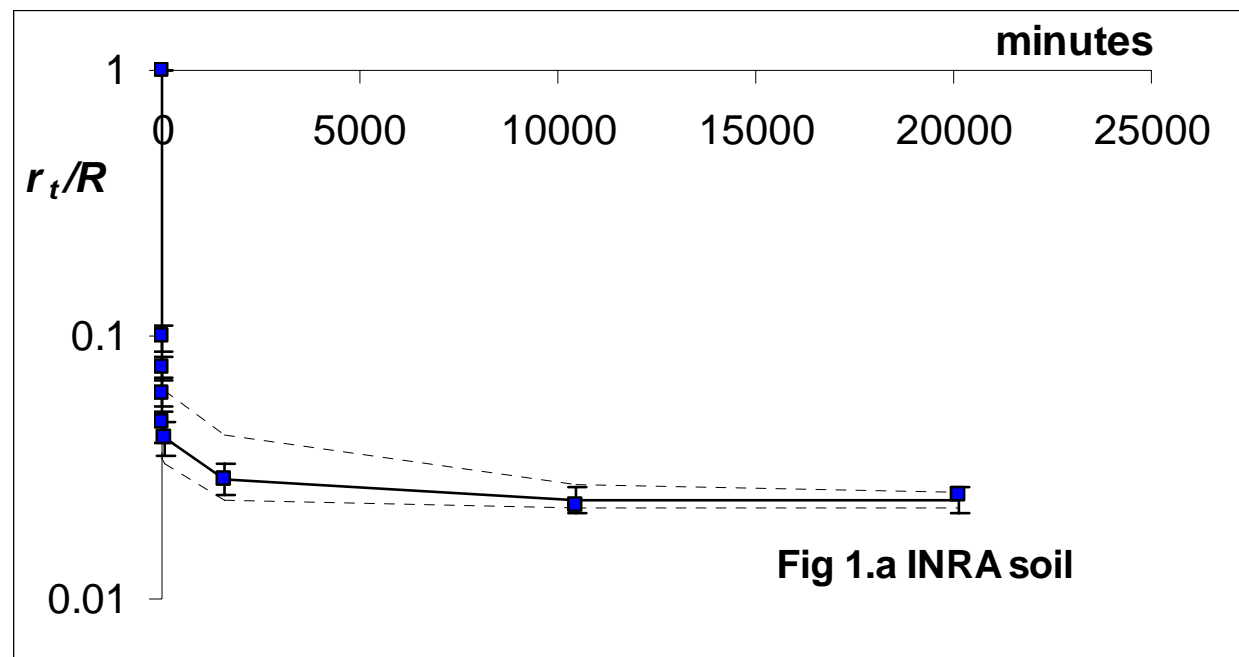

743

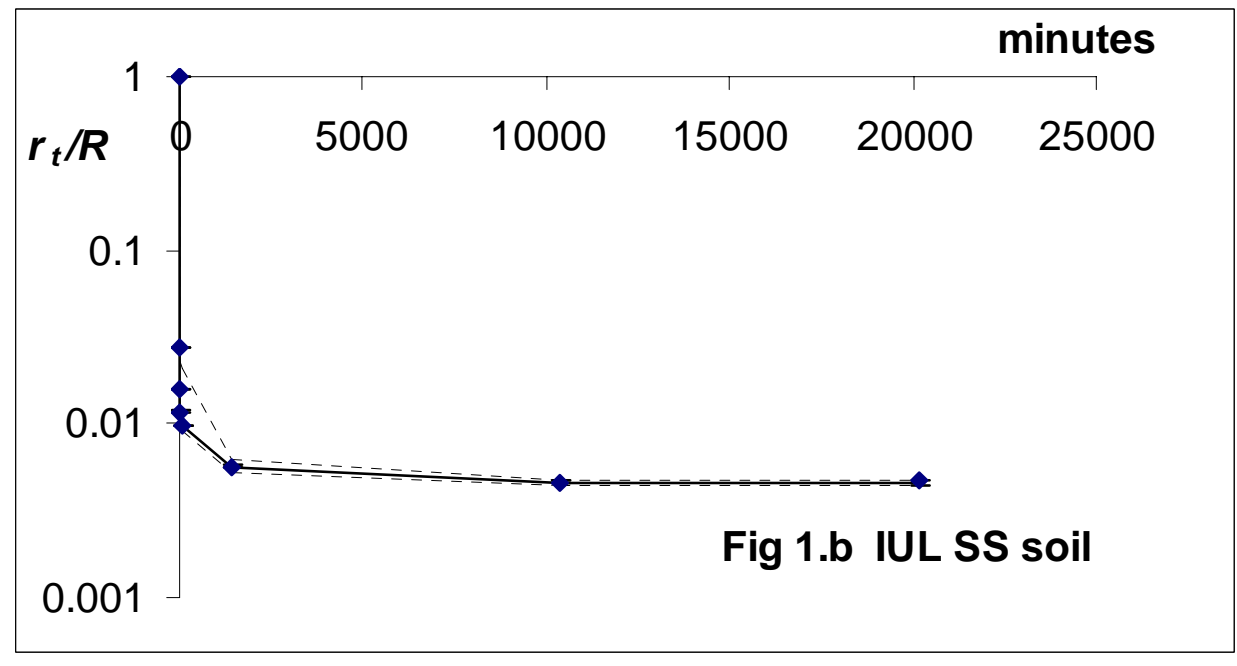

744

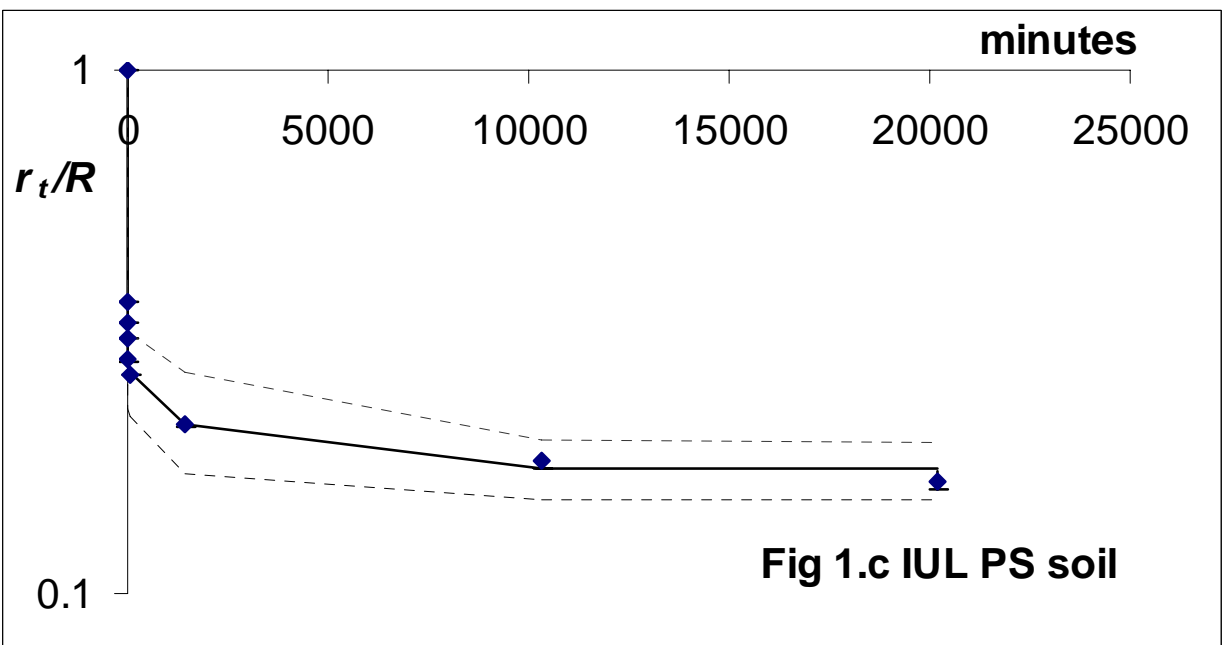




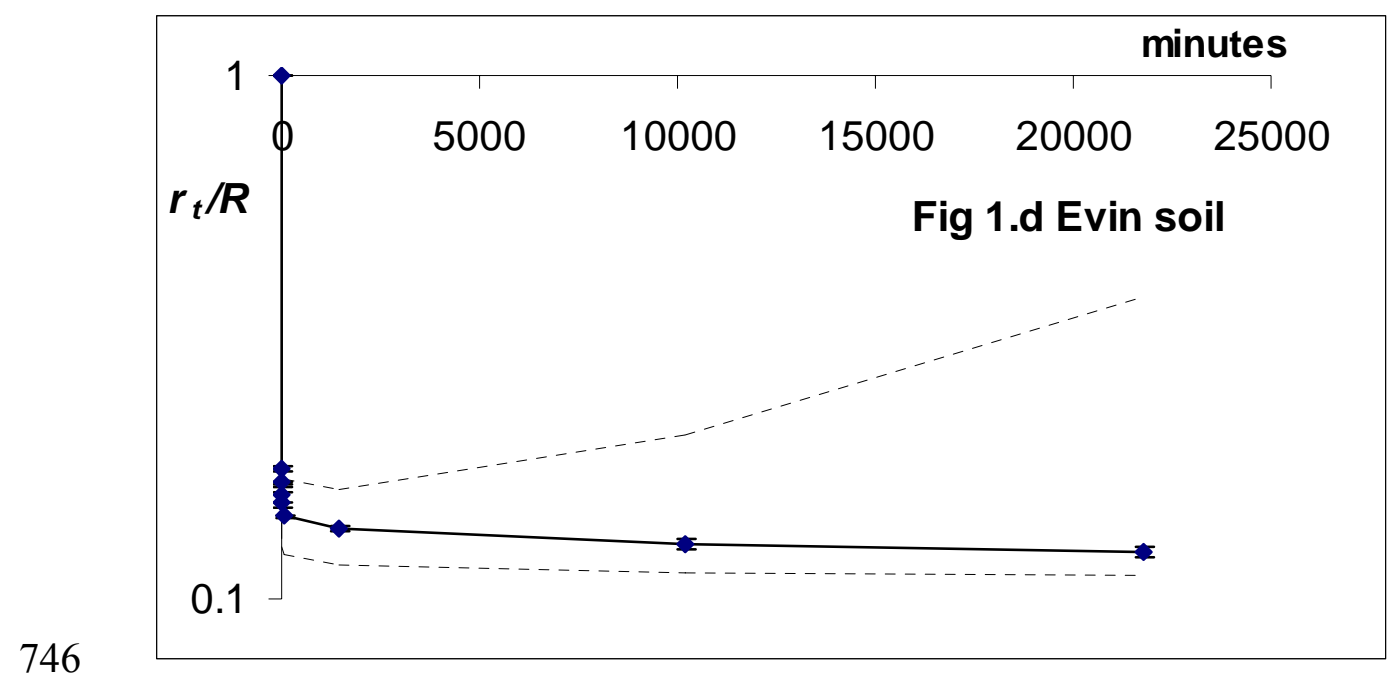

747
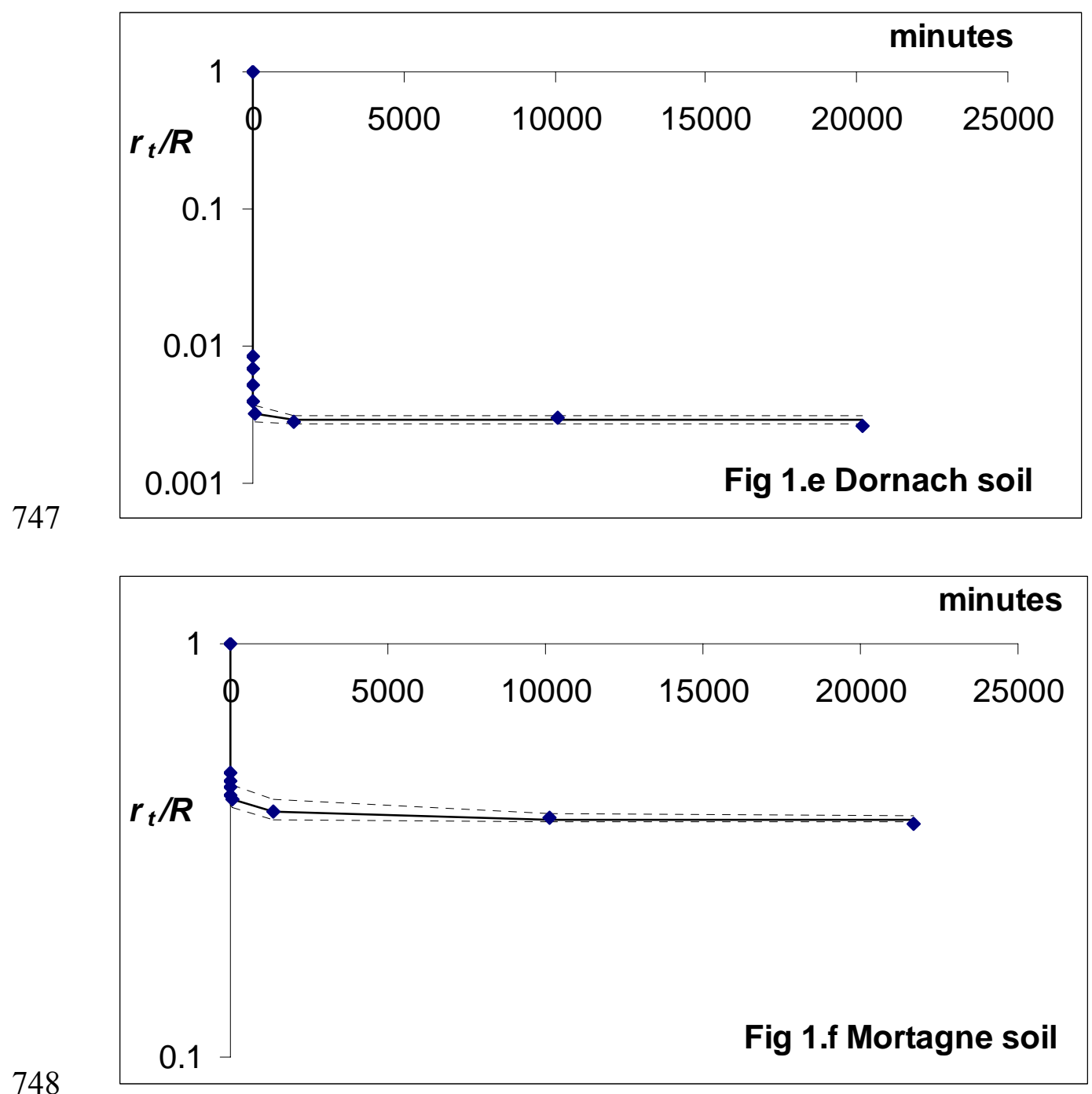
Figure 2

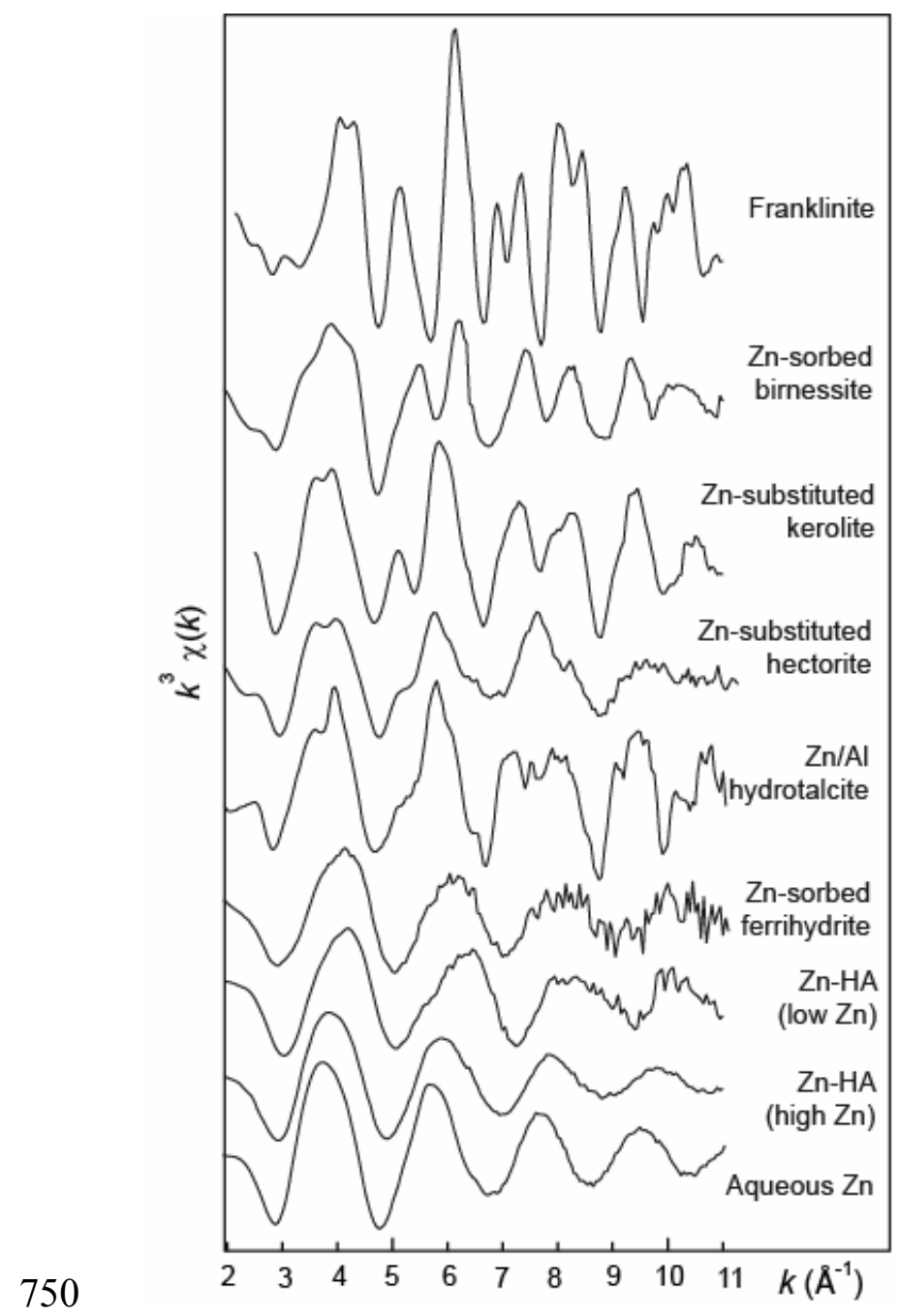


$751 \quad$ Figure 3

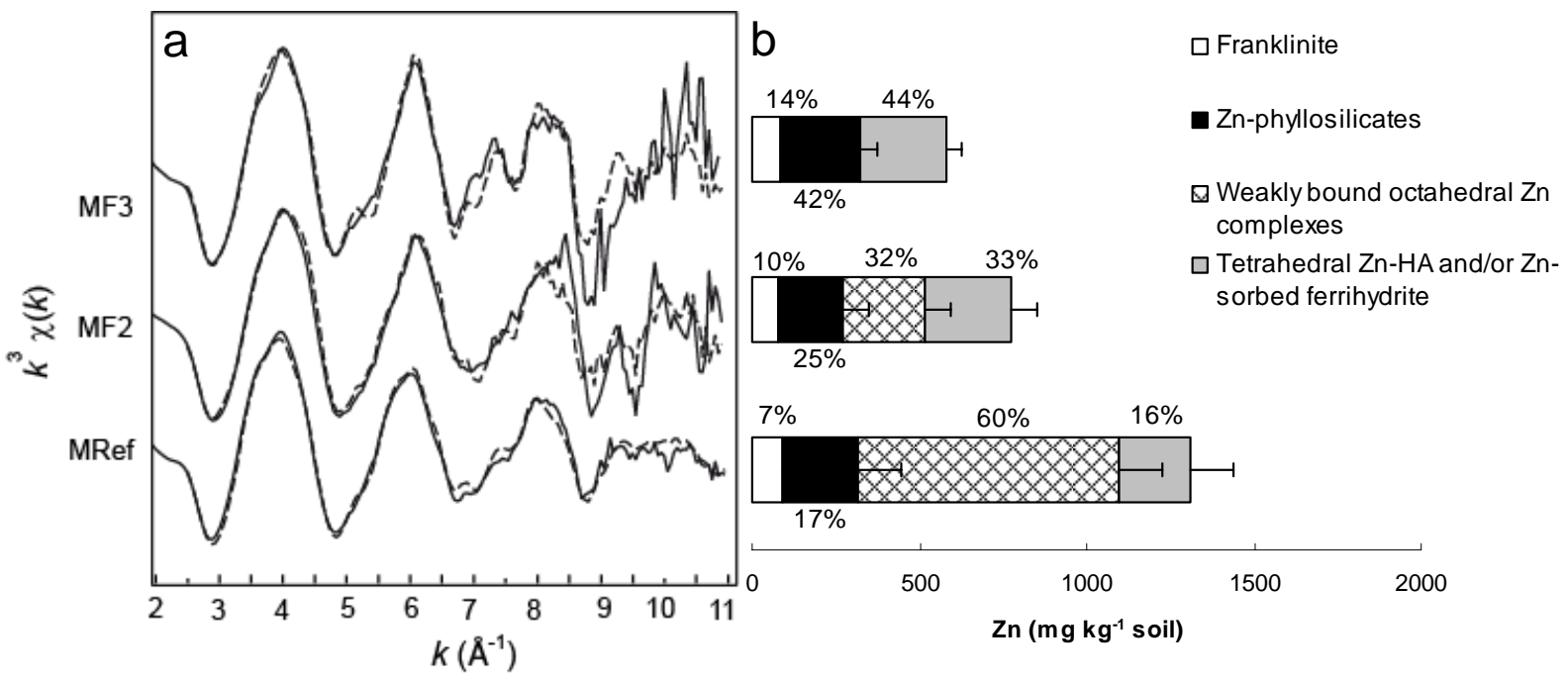


Figure 4

753

754

755

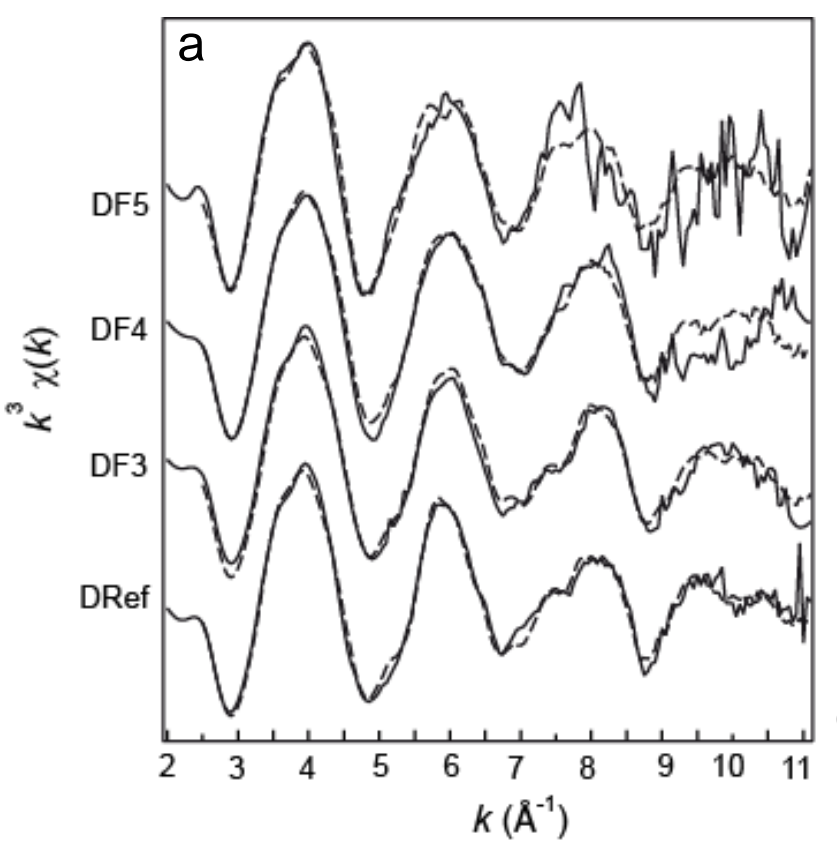

b

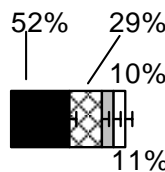

$20 \% \quad 66 \% \quad 14 \%$

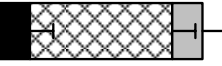

$28 \%$

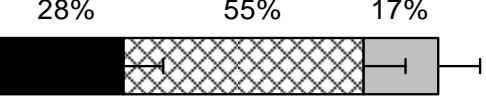

$27 \%$

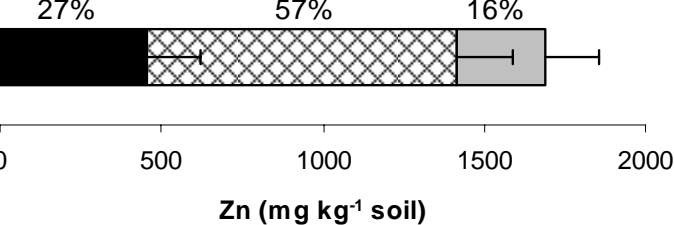

$\square$ Weakly bound octahedral Zn complexes

$\square$ Tetrahedral Zn-HA and/or Zn-sorbed ferrihydrite

$\square \mathrm{Zn}$-sorbed birnessite 
Table 1 Selected characteristics of the six soils polluted with heavy metals

\begin{tabular}{|c|c|c|c|c|c|c|}
\hline Characteristic & INRA & IUL SS & IUL PS & Evin & Dornach & Mortagne \\
\hline Soil type & Eutric Fluvisol & Orthic Luvisol & Orthic Luvisol & Gleyic Luvisol & Calcaric Regosol & Dystric Cambisol \\
\hline Pollutant source & Sewage Sludge & Sewage Sludge & Pig Slurry & $\mathrm{Pb} / \mathrm{Zn}$ Smelter & $\mathrm{Cu} / \mathrm{Ni} / \mathrm{Zn}$ Smelter & Zn Smelter \\
\hline Land use & arable & Arable & Arable & forest & grassland & grassland \\
\hline Sampling depth / cm & $0-20$ & $0-20$ & $0-20$ & $2-5$ & $2-5$ & $5-40$ \\
\hline Sand $/ \%{ }^{\mathrm{a}}$ & 80 & 57 & 58 & 28 & 15 & 66 \\
\hline Clay $/ \%^{\mathrm{a}}$ & 7 & 15 & 15 & 20 & 37 & 7 \\
\hline Organic matter $/ \%^{b}$ & 2 & 3 & 2 & 4 & 11 & 1 \\
\hline $\mathrm{CaCO}_{3} / \%{ }^{\mathrm{c}}$ & n.d. & n.d. & n.d. & n.d. & 5 & n.d. \\
\hline Oxalate extractable $\mathrm{Fe} / \mathrm{g} \mathrm{kg}^{-1}$ soil $^{\mathrm{d}}$ & 2.14 & 11.11 & 5.11 & 3.17 & 2.70 & 1.88 \\
\hline EDTA extractable $\mathrm{Zn} / \mathrm{mg} \mathrm{kg}^{-1}$ soil $^{\mathrm{e}}$ & 166 & 15 & 9 & 435 & 349 & 406 \\
\hline $\mathrm{pH}^{\mathrm{f}}$ & 5.7 & 6.0 & 4.6 & 5.0 & 6.7 & 5.1 \\
\hline $\mathrm{CEC} / \mathrm{mmol}_{\mathrm{c}} \mathrm{kg}^{-1 \mathrm{~g}}$ & 101 & 164 & 161 & 185 & 432 & 67 \\
\hline Base saturation $/ \%^{\mathrm{g}}$ & 47.8 & 17.5 & 45.2 & 85.6 & 42.2 & 18.8 \\
\hline Total $\mathrm{Zn} / \mathrm{mg} \mathrm{kg}^{-1}$ soil $^{\mathrm{i}}$ & $680 \quad(5.4)$ & $162(0.5)$ & $87.9(1.7)$ & $1647(3.1)$ & $1687 \quad(3.1)$ & $1307 \quad(8.7)$ \\
\hline
\end{tabular}

n.d. non detectable

${ }^{a}$ Soil texture was measured via sedimentation with $\left(\mathrm{NaPO}_{4}\right)_{6}$ as a dispersion agent (FAL, RAC \& FAW, 1996).

${ }^{\mathrm{b}}$ Organic matter was measured by titration (FAL, RAC \& FAW, 1996).

${ }^{\mathrm{c}} \mathrm{CaCO}_{3}$ was quantified using concentrated $\mathrm{HCl}$ (FAL, RAC \& FAW, 1996).

d Oxalate extractable Fe was determined according to Loeppert and Inskeep (1996).

${ }^{\mathrm{e}}$ EDTA-NH $\mathrm{NAc}_{4}$ extractions were performed using 50ml of extractant added to $10 \mathrm{~g}$ dry soil (FAL, RAC \& FAW, 1996).

${ }^{\mathrm{f}} \mathrm{pH}$ was measured using a 1:2.5 soil solution ratio of $0.01 \mathrm{M} \mathrm{CaCl}_{2}$ after 24 hours of gentle shaking.

${ }^{\mathrm{g}} \mathrm{CEC}$ and base saturation were determined using $\mathrm{BaCl}_{2}$ method (FAL, RAC \& FAW, 1996).

${ }^{i}$ Total $\mathrm{Zn}$ obtained after direct digestion $(\mathrm{n}=3)$ and standard error (in parentheses). 
759 Table 2 Selective sequential extraction used for the fractionation of Zn based on Salbu et al. (1998) and Lorentzen and Kingston (1996)

760

\begin{tabular}{|c|c|c|c|}
\hline Extraction step & Reagents & Procedure & Proposed binding mechanism targeted ${ }^{\mathrm{a}}$ \\
\hline $\mathrm{F} 1$ & $\mathrm{H}_{2} \mathrm{O}$ & 1 hours at $20^{\circ} \mathrm{C}$ & Water soluble \\
\hline $\mathrm{F} 2$ & $1 \mathrm{M} \mathrm{NH}_{4} \mathrm{OAc}, \mathrm{pH} 7$ & 2 hours at $20^{\circ} \mathrm{C}$ & Reversible physisorption \\
\hline $\mathrm{F} 3$ & $1 \mathrm{M} \mathrm{NH}_{4} \mathrm{OAc}, \mathrm{pH} 5\left(\mathrm{HNO}_{3}\right)$ & 2 hours at $20^{\circ} \mathrm{C}$ & Reversible electrosorption \\
\hline \multirow[t]{2}{*}{ F4 } & $\begin{array}{l}0.04 \mathrm{M} \mathrm{NH}_{2} \mathrm{OH}-\mathrm{HCl} \text { in } \\
4.4 \mathrm{M} \mathrm{CH}_{3} \mathrm{COOH}\end{array}$ & 6hours at $80^{\circ} \mathrm{C}$ & Irreversible chemisorption / reduction \\
\hline & 9.7 $\mathrm{M} \mathrm{H}_{2} \mathrm{O}_{2}, \mathrm{pH} 2\left(\mathrm{HNO}_{3}\right)$ & 5.5 hours at $80^{\circ} \mathrm{C}$ & \\
\hline \multirow[t]{2}{*}{ F5 } & followed by & & Chemisorption / oxidation \\
\hline & $3.2 \mathrm{M} \mathrm{NH}_{4} \mathrm{OAc}$ in $4.4 \mathrm{M} \mathrm{HNO}_{3}$ & 30 minutes at $20^{\circ} \mathrm{C}$ & \\
\hline F6 & $7 \mathrm{M} \mathrm{HNO}_{3}$ & 6 hours at $20^{\circ} \mathrm{C}$ & Chemisorption / crystalline \\
\hline \multicolumn{4}{|l|}{ Total Digestion } \\
\hline F7 & $\begin{array}{l}\mathrm{HNO}_{3}, \mathrm{H}_{2} \mathrm{O}_{2} \text { and } \mathrm{HCl} \text { Open- } \\
\text { Microwave Digestion }\end{array}$ & 45 minutes at $70^{\circ}, 90^{\circ} \mathrm{C}$ & Residue \\
\hline
\end{tabular}

${ }^{a}$ Proposed by Salbu et al. (1998) 
761 Table 3 Average $\mathrm{Zn}$ concentration in dilute $\mathrm{CaCl}_{2}$ extracts $\left(C_{\mathrm{Zn}}\right)$ measured during the isotopic exchange experiments and amounts of $\mathrm{Zn}$

762 exchangeable within 1 minute $\left(E_{\text {pool1 }}\right)$, moderately isotopically exchangeable $\mathrm{Zn}\left(E_{\text {pool2 }}\right)$ and slowly or not exchangeable $\mathrm{Zn}\left(E_{\text {pool3 }}\right)$

763 calculated for six soils polluted with heavy metals. The average data is followed by the standard error (se) given between parentheses.

\begin{tabular}{|c|c|c|c|c|c|c|c|c|}
\hline \multirow[t]{3}{*}{ Soil } & \multicolumn{2}{|l|}{$C_{\mathrm{Zn}}$} & \multicolumn{2}{|c|}{$E_{\text {pool1 }}$} & \multicolumn{2}{|c|}{$E_{\text {pool2 }}$} & \multicolumn{2}{|c|}{$E_{\text {pool3 }}$} \\
\hline & Average & $\mathrm{Se}$ & Average & se & Average & se & Average & se \\
\hline & n 1 & & & & $\operatorname{mg~Zn~} 1$ & oil & & \\
\hline INRA & 0.50 & 0.030 & 50.7 & $(3.0)$ & 167 & $(5.9)$ & 463 & $(8.8)$ \\
\hline IUL SS & 0.02 & 0.003 & 5.7 & $(0.6)$ & 28.6 & $(2.5)$ & 128 & (3.1) \\
\hline IUL PS & 0.38 & 0.006 & 10.5 & $(0.3)$ & 12.6 & $(0.9)$ & 64.8 & $(0.7)$ \\
\hline Evin & 12.4 & 0.149 & 697 & (11.6) & 305 & (14.4) & 645 & $(10.6)$ \\
\hline Dornach & 0.15 & 0.007 & 181 & (1.9) & 368 & (18.5) & 1138 & (18.6) \\
\hline Mortagne & 29.9 & 0.429 & 612 & $(10.2)$ & 174 & (4.1) & 521 & $(7.0)$ \\
\hline
\end{tabular}


765 Table 4 Average values for plant aerial dry matter, Zn content of aerial parts and $L$ value measured with Thlaspi caerulescens in six soils 766 polluted with heavy metals. The standard errors (se) are given between parentheses.

767

\begin{tabular}{|c|c|c|c|c|c|c|}
\hline \multirow[t]{3}{*}{ Soil } & \multicolumn{2}{|c|}{ Yield } & \multicolumn{2}{|c|}{ Plant $\mathrm{Zn}$ content } & \multicolumn{2}{|c|}{$L$ value } \\
\hline & Average & se & Average & $\mathrm{se}$ & Average & se \\
\hline & \multicolumn{2}{|c|}{ / $\mathrm{g} \mathrm{DM} \mathrm{kg}^{-1}$ soil } & \multicolumn{2}{|c|}{$/ \mathrm{g} \mathrm{kg}^{-1} \mathrm{DM}$} & \multicolumn{2}{|c|}{$/ \mathrm{mg} \mathrm{Zn} \mathrm{kg}^{-1}$ soil } \\
\hline INRA & 16.5 & $(0.5)$ & 0.4 & $(0.1)$ & 224 & $(14.0)$ \\
\hline IUL SS & 23.4 & $(0.3)$ & 1.2 & $(0.1)$ & 36 & $(0.2)$ \\
\hline IUL PS & 20.6 & (1.1) & 1 & $(0.1)$ & 22.6 & $(0.7)$ \\
\hline Evin & 21.7 & $(0.4)$ & 4 & $(0.5)$ & 828 & (14.1) \\
\hline Dornach & 20.4 & $(0.8)$ & 2.2 & $(0.5)$ & 564 & $(0.8)$ \\
\hline Mortagne & 21.7 & $(0.7)$ & 5.9 & $(0.3)$ & 737 & $(4.7)$ \\
\hline
\end{tabular}


768 Table 5 Average amount of $\mathrm{Zn}$ recovered in the different fractions of the selective sequential extraction after 20, 85 and 120 days of

769 incubation in six soils polluted by heavy metals. The results are expressed in $\mathrm{mg} \mathrm{Zn} \mathrm{kg}{ }^{-1}$ soil and the standard errors (se) are given between 770 parentheses.

771

\begin{tabular}{|c|c|c|c|c|c|c|c|c|c|c|c|c|}
\hline \multirow[t]{3}{*}{ Fractions } & \multicolumn{2}{|c|}{ INRA } & \multicolumn{2}{|c|}{ IUL SS } & \multicolumn{2}{|c|}{ IUL PS } & \multicolumn{2}{|c|}{ Evin } & \multicolumn{2}{|c|}{ Dornach } & \multicolumn{2}{|c|}{ Mortagne } \\
\hline & Average & se & Average & se & Average & se & Average & se & Average & se & Average & se \\
\hline & & & & & & $/ \mathrm{mg}$ & $\mathrm{g}^{-1}$ soil & & & & & E \\
\hline F1 & 2 & $(0.5)$ & 0.2 & $(0.1)$ & 1.2 & $(0.5)$ & 23.7 & $(6.8)$ & 1.2 & $(0.5)$ & 28.1 & $(3.8)$ \\
\hline F2 & 26.7 & (1.8) & 1.8 & $(0.2)$ & 2.5 & $(0.2)$ & 499 & (27.9) & 78.7 & $(4.2)$ & 505 & $(26.0)$ \\
\hline $\mathrm{F} 3$ & 103 & (11.7) & 10.4 & (1.6) & 8 & $(0.9)$ & 248 & (2.9) & 246 & (23.4) & 195 & $(4.8)$ \\
\hline F4 & 217 & $(10.0)$ & 55.1 & (3.5) & 19.8 & $(1.0)$ & 362 & (22.1) & 696 & $(44.8)$ & 285 & $(20.1)$ \\
\hline F5 & 71.6 & (21.5) & 24.4 & (2.3) & 11.2 & (1.6) & 256 & (18.1) & 317 & (48.9) & 64 & $(11.0)$ \\
\hline F6 & 279 & (38.6) & 74.9 & (10.6) & 43.6 & (4.9) & 256 & $(36.8)$ & 165 & (37.6) & 101 & $(11.9)$ \\
\hline F7 & 10.1 & $(2.2)$ & 21.4 & (2.7) & 12.0 & (2.9) & 45.0 & (10.9) & 28.9 & $(5.1)$ & 26.2 & $(4.8)$ \\
\hline Total extracted & 709 & (19.5) & 188 & (12.6) & 98.2 & $(6.0)$ & 1690 & (42.3) & 1533 & (64.5) & 1205 & $(51.2)$ \\
\hline
\end{tabular}


775 Table 6 Mean specific activities calculated for each fraction of the selective sequential extraction over 120 days for 6 soils polluted with

776 heavy metals. The values for each fraction are normalized by the ${ }^{65} \mathrm{Zn}$ introduced and the total soil $\mathrm{Zn}$. Standard errors (se) are given

777 between parentheses.

778

\begin{tabular}{|c|c|c|c|c|c|c|c|c|c|c|c|c|}
\hline \multirow[t]{2}{*}{ Fraction } & \multicolumn{2}{|c|}{ INRA } & \multicolumn{2}{|c|}{ IUL SS } & \multicolumn{2}{|c|}{ IUL PS } & \multicolumn{2}{|c|}{ Evin } & \multicolumn{2}{|c|}{ Dornach } & \multicolumn{2}{|c|}{ Mortagne } \\
\hline & Average & se & Average & se & Average & se & Average & se & Average & se & Average & se \\
\hline $\mathrm{F} 1$ & 1.95 & $(0.21)$ & 1.15 & $(0.16)$ & 2.42 & $(0.86)$ & 1.32 & $(0.38)$ & 1.22 & $(0.43)$ & 1.10 & $(0.16)$ \\
\hline $\mathrm{F} 2$ & 2.51 & $(0.05)$ & 4.24 & $(0.12)$ & 3.54 & $(0.28)$ & 1.53 & $(0.12)$ & 2.10 & $(0.29)$ & 1.25 & $(0.05)$ \\
\hline F3 & 2.26 & $(0.11)$ & 3.48 & $(0.26)$ & 3.10 & $(0.17)$ & 1.65 & $(0.10)$ & 1.80 & $(0.06)$ & 1.27 & $(0.05)$ \\
\hline F4 & 1.67 & $(0.10)$ & 1.89 & $(0.19)$ & 2.27 & $(0.17)$ & 1.00 & $(0.11)$ & 0.70 & $(0.04)$ & 0.58 & $(0.08)$ \\
\hline F5 & 0.49 & $(0.06)$ & 0.38 & $(0.01)$ & 0.47 & $(0.02)$ & 0.37 & $(0.06)$ & 0.42 & $(0.06)$ & 0.17 & $(0.03)$ \\
\hline F6 & 0.01 & $(0.01)$ & 0.07 & $(0.02)$ & 0.08 & $(0.02)$ & 0.12 & $(0.03)$ & 0.22 & $(0.08)$ & 0.04 & $(0.01)$ \\
\hline F7 & 0.01 & $(0.01)$ & 0.02 & $(0.01)$ & 0.02 & $(0.01)$ & 0.04 & $(0.02)$ & 0.08 & $(0.02)$ & 0.01 & $0.00)$ \\
\hline
\end{tabular}


780 Table 7 Comparison of the data obtained by the various techniques

781

\begin{tabular}{|c|c|c|c|c|c|c|}
\hline Soil & INRA & IUL-SS & IUL-PS & Evin & Dornach & Mortagne \\
\hline $\begin{array}{l}\text { Total Zn } \\
\text { / mg Zn kg soil }{ }^{-1}\end{array}$ & 680 & 162 & 87.9 & 1647 & 1687 & 1307 \\
\hline $\mathrm{pH}$ & 5.7 & 6.0 & 4.6 & 5.0 & 6.7 & 5.1 \\
\hline $\begin{array}{l}\text { Concentration of } \\
\mathrm{Zn} \text { in } \mathrm{CaCl}_{2} ; C_{\mathrm{Zn}} \\
/ \mathrm{mg} \mathrm{Zn} \mathrm{l}^{-1}\end{array}$ & 0.50 & 0.01 & 0.38 & 12.3 & 0.15 & 29.9 \\
\hline $\begin{array}{l}E_{\text {pool1 }} / E_{\text {pool } 2 / E_{\text {pool3 }}} \\
/ \mathrm{mg} \mathrm{Zn} \mathrm{kg} \mathrm{soil}^{-1}\end{array}$ & $50.7 / 167 / 463$ & $5.7 / 28.6 / 128$ & $10.5 / 12.6 / 64.8$ & 697 / 305 / 645 & $181 / 368 / 1138$ & $612 / 174 / 521$ \\
\hline $\begin{array}{l}L \text { values } \\
/ \mathrm{mg} \mathrm{Zn} \mathrm{kg} \mathrm{soil}^{-1}\end{array}$ & 224 & 36 & 22.6 & 828 & 564 & 737 \\
\hline $\begin{array}{l}\text { Extraction steps, by } \\
\text { decreasing order of } \\
\mathrm{Zn} \text { recovery }\end{array}$ & $\begin{array}{c}\mathrm{F} 6>\mathrm{F} 4>\mathrm{F} 3> \\
\mathrm{F} 5>\mathrm{F} 2>\mathrm{F} 7>\mathrm{F} 1\end{array}$ & $\begin{array}{c}\mathrm{F} 6>\mathrm{F} 4>\mathrm{F} 5> \\
\mathrm{F} 7>\mathrm{F} 3>\mathrm{F} 2>\mathrm{F} 1\end{array}$ & $\begin{array}{c}\mathrm{F} 6>\mathrm{F} 4>\mathrm{F} 7> \\
\mathrm{F} 5>\mathrm{F} 3>\mathrm{F} 2>\mathrm{F} 1\end{array}$ & $\begin{array}{c}\mathrm{F} 2>\mathrm{F} 4>\mathrm{F} 6- \\
\mathrm{F} 5> \\
\mathrm{F} 3>\mathrm{F} 7>\mathrm{F} 1\end{array}$ & $\mathrm{~F} 4>\mathrm{F} 5>\mathrm{F} 3>\mathrm{F} 6>\mathrm{F} 2>\mathrm{F} 7>\mathrm{F} 1$ & $\mathrm{~F} 2>\mathrm{F} 4>\mathrm{F} 3>\mathrm{F} 6>\mathrm{F} 5>\mathrm{F} 1>\mathrm{F} 7$ \\
\hline $\begin{array}{l}\text { Distribution of } \mathrm{Zn} \\
\text { species in the } \\
\text { untreated soil / \% }{ }^{\mathrm{a}}\end{array}$ & & & & & $\begin{array}{l}57 \% \text { weakly bound } \\
\text { octahedral Zn }+ \\
27 \% \text { Zn- phyllosilicates + } \\
16 \% \text { tetrahedral Zn-HA } \\
\text { and/or Zn-sorbed } \\
\text { ferrihydrite }\end{array}$ & $\begin{array}{l}60 \% \text { weakly bound } \\
\text { octahedral Zn }+17 \% \text { Zn- } \\
\text { phyllosilicates }+16 \% \\
\text { tetrahedral Zn-HA and/or } \\
\text { Zn-sorbed ferrihydrite }+7 \% \\
\text { franklinite }\end{array}$ \\
\hline $\begin{array}{l}\text { Comparison of } \\
\text { results obtained by } \\
\text { the different } \\
\text { methods } \\
/ \mathrm{mg} \mathrm{Zn} \mathrm{kg} \mathrm{soil}^{-1}\end{array}$ & & & & & $\begin{array}{l}\mathrm{F} 1+\mathrm{F} 2+\mathrm{F} 3+\mathrm{F} 4(1023)= \\
\text { weakly bound octahedral } \mathrm{Zn} \\
(962)>E_{\text {pool1 }}+E_{\text {pool2 }}(549)> \\
\mathrm{F} 1+\mathrm{F} 2+\mathrm{F} 3(326)\end{array}$ & $\begin{array}{l}\mathrm{F} 1+\mathrm{F} 2+\mathrm{F} 3+\mathrm{F} 4(1014)> \\
\text { weakly bound octahedral } \mathrm{Zn} \\
(784)=E_{\text {pooll }}+E_{\text {pool2 }}(786)= \\
\mathrm{F} 1+\mathrm{F} 2+\mathrm{F} 3(729)\end{array}$ \\
\hline
\end{tabular}

${ }^{a}$ Determined only for Dornach and Mortagne soils. 